\title{
Discovery of Turn-On Fluorescent Probes for Detecting PDES Protein in Living Cells and Tumor Slices
}

Gaopan Dong ${ }^{\mathrm{a}, \dagger}$, Long Chen ${ }^{\mathrm{b}, \dagger}$, Jing Zhang ${ }^{\mathrm{c},}$, Tingting Liu ${ }^{\mathrm{a}, \mathrm{d}}$, Lupei $\mathrm{Du}^{\mathrm{a}}$, Chunquan Sheng $\mathrm{b}^{*}$ and Minyong $\mathrm{Li}^{\mathrm{a},{ }^{*}}$

${ }^{a}$ Department of Medicinal Chemistry, Key Laboratory of Chemical Biology (MOE), School of Pharmaceutical Sciences, Cheeloo College of Medicine, Shandong University, Shandong University, Jinan, Shandong 250012, China.

${ }^{\mathrm{b}}$ Department of Medicinal Chemistry, School of Pharmacy, Second Military Medical University, Shanghai 200433, China.

${ }^{c}$ Department of Pathology, Changhai Hospital, Second Military Medical University, Shanghai 200433, China.

d Institute of Pharmacology, School of Pharmaceutical Sciences, Shandong First Medical University \& Shandong Academy of Medical Sciences, Taian 271000, Shandong, China.

${ }^{+}$Authors contributed equally to this work.

*Corresponding Author: Tel/Fax: +86-531-8838-2076. Email: mli@sdu.edu.cn; shengcq@smmu.edu.cn. Table of Contents

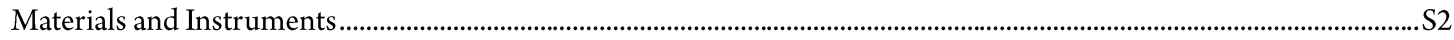

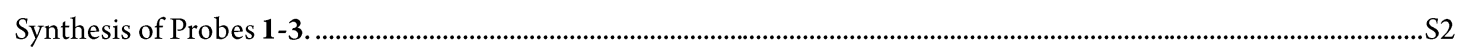

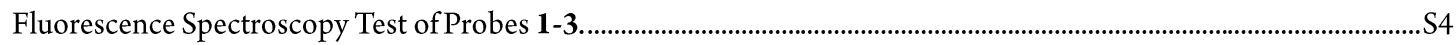

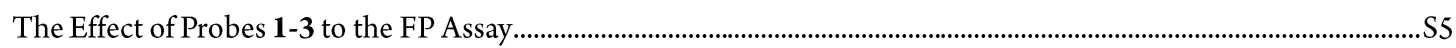

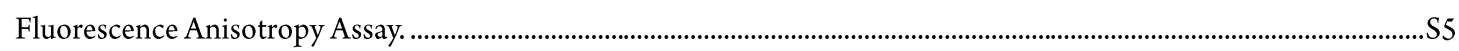

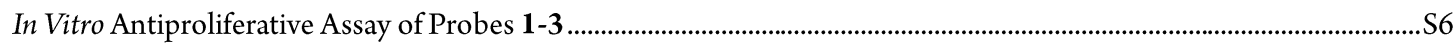

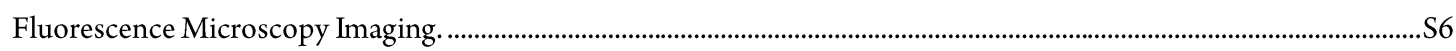

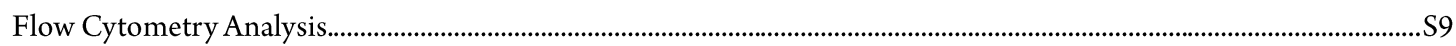

Total RNA Preparation, cDNA Synthesis, and quantitative Real-time PCR ........................................................................

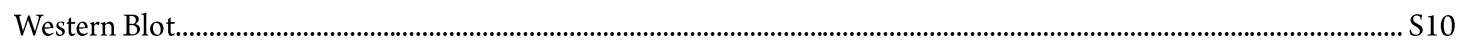

Immunohistochemical Analysis of Paraffin Embedded Capan-1 1..............................................................................S11

Imaging Analysis of Paraffin Embedded Capan-1 and HeLa Tumor Slices.....................................................................S11

NMR and HRMS Spectra of Probes 1-3 .......................................................................................................................... S12

HPLC Assessment of the Products Purity ........................................................................................................................ S19

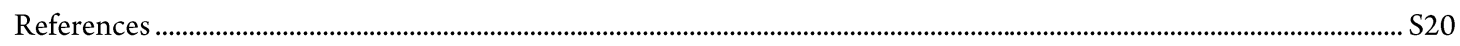




\section{Materials and Instruments}

General chemicals available from commercial sources and used as received without further purified. The $\mathrm{ddH}_{2} \mathrm{O}$ was used for the biological evaluation studies. Buffer reagents were purchased from Aldrich and Acros. HRMS spectra were performed by the mass spectrometry facilities in the Shandong Analysis and Test Center. ${ }^{1} \mathrm{H}$ NMR and ${ }^{13} \mathrm{C}$ NMR were recorded on a Bruker $300 \mathrm{MHz} / 600 \mathrm{MHz}$ NMR spectrometer. Fluorescence spectra and absorption spectra were tested by the Bio Tek Instruments microplate reader. Fluorescence imaging of cells was performed by the Zeiss Axio Observer A1 fluorescence microscope. Quantum yields of probes 1-3 were measured by HitachiF-2500 fluorescent spectrometer, Shimadzu UV-2401PC UV-visible spectrometer and WAY-2S Abbe refractometer. Analytical HPLC was performed on Agilent Technologies 1260 Series with a C18 reversed phase column $(250 \times 4.60 \mathrm{~mm}$, Phenomenex $)$. IHC and tissue slice images were performed on OLYMPUS VS120. Flow cytometry was analyzed by Beckman CytoFLEX Cell Counter. qPCR were preformed by a LightCycler ${ }^{\circledR} 6$ SW 1.1 (Roche, Switzerland).

\section{Synthesis of Probes 1-3.}

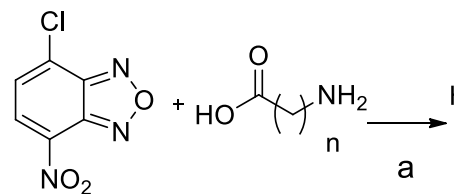<smiles>O=C1c2ccccc2NC(c2ccccc2F)N1C1CCN(Cc2ccccc2)CC1</smiles>

7<smiles>CC(Nc1ccc([N+](=O)[O-])c2nonc12)C(=O)O</smiles>
4-6<smiles>O=C1c2ccccc2NC(c2ccccc2F)N1C1CCNCC1</smiles>
8<smiles>C=CCC1Nc2ccccc2C(=O)N1C1CCN(C(=O)CNc2ccc([N+](=O)[O-])c3nonc23)CC1</smiles>

Scheme 1. Reagents and conditions: a) $\mathrm{NaHCO}_{3}, \mathrm{MeOH}$, r.t., 24 h, 62\%-77\%; b) $\mathrm{H}_{2}, \mathrm{Pd}(\mathrm{OH})_{2}, \mathrm{MeOH}$, r.t., overnight, $85 \%$; c) HBTU, TEA, DMF, r.t., 2 h, 16\%-53\%.<smiles>O=C(O)CNc1ccc([N+](=O)[O-])c2nonc12</smiles>

2-((7-Nitrobenzo[c] $[1,2,5]$ oxadiazol-4-yl) amino) acetic acid (4).

4-Chloro-7-nitrobenzo[c][1,2,5] oxadiazole $(100 \mathrm{mg}, 0.5 \mathrm{mmol})$ and 2-aminoacetic acid (38 mg, $0.5 \mathrm{mmol})$ was dissolved in $5 \mathrm{~mL} \mathrm{MeOH}$ under nitrogen. The mixture was stirred at room temperature for $24 \mathrm{~h}$. The solvent was removed under reduced pressure. The residue was washed with $5 \mathrm{~mL} \mathrm{Et}_{2} \mathrm{O}$, and then it was dissolved in $20 \mathrm{~mL}$ water. The $\mathrm{pH}$ was adjusted to 3-4. The brown solid was precipitated and filtered to afford the pure product, yield: $65 \% .{ }^{1} \mathrm{H}$ NMR (300 MHz, DMSO-d $): \delta 8.48(\mathrm{~d}, 1 \mathrm{H}, J=8.5 \mathrm{~Hz}), 6.20(\mathrm{~d}, 1 \mathrm{H}, J=8.5 \mathrm{~Hz}), 3.77(\mathrm{~s}, 2 \mathrm{H})$.<smiles>O=C(O)CCNc1ccc([N+](=O)[O-])c2nonc12</smiles>

3-((7-Nitrobenzo $[c][1,2,5]$ oxadiazol-4-yl)amino) propanoic acid (5)

Brown solid, yield: $77 \% .{ }^{~} \mathrm{H}$ NMR $\left(300 \mathrm{MHz}, \mathrm{D}_{2} \mathrm{O}\right): \delta 8.48(\mathrm{~d}, 1 \mathrm{H}, J=8.9 \mathrm{~Hz}), 6.36(\mathrm{~d}, 1 \mathrm{H}, J=8.9 \mathrm{~Hz}), 3.77(\mathrm{~s}, 2 \mathrm{H})$, $2.73(\mathrm{t}, 2 \mathrm{H}, J=6.4 \mathrm{~Hz})$. 
<smiles>O=C(O)CCCNc1ccc([N+](=O)[O-])c2nonc12</smiles>

4-((7-Nitrobenzo[c] $][1,2,5]$ oxadiazol-4-yl)amino)butanoic acid (6)

Brown solid, yield: $62 \%$. ${ }^{1} \mathrm{H}$ NMR $\left(300 \mathrm{MHz}\right.$, DMSO- $\left.d_{6}\right): \delta 9.56(\mathrm{~s}, 1 \mathrm{H}), 8.52(\mathrm{~d}, 1 \mathrm{H}, J=7.8 \mathrm{~Hz}), 6.44(\mathrm{~d}, 1 \mathrm{H}, J=7.8$ $\mathrm{Hz}), 3.50(\mathrm{~s}, 2 \mathrm{H}), 2.37(\mathrm{t}, 1 \mathrm{H}, J=7.6 \mathrm{~Hz}), 1.88-1.90(\mathrm{~m}, 2 \mathrm{H})$.<smiles>O=C1c2ccccc2NC(c2ccccc2F)N1C1CCNCC1</smiles>

2-(2-Fluorophenyl)-3-(piperidin-4-yl)-2,3-dihydroquinazolin-4(1H)-one (8)

Compound $\mathbf{8}$ was prepared according the literature, yield: $85 \%$. The ${ }^{1} \mathrm{H}$ NMR spectrum and mess spectrum were consistent with the literature. ${ }^{1}$<smiles>O=C(CNc1ccc([N+](=O)[O-])c2nonc12)N1CCC(N2C(=O)c3ccccc3NC2c2ccccc2F)CC1</smiles>

2-(2-Fluorophenyl)-3-(1-(2-((7-nitrobenzo[c] $]$ 1,2,5] oxadiazol-4-yl)amino)acetyl)piperidin-4-yl)-2,3dihydroquinazolin-4(1H)-one (Probe 1$)$

Compound $4(50 \mathrm{mg}, 0.21 \mathrm{mmol}), 8(70 \mathrm{mg}, 0.21 \mathrm{mmol}), 2$-(1H-benzotriazol-1-yl)-1,1,3,3-tetramethyluronium hexauorophosphate (HBTU) $(160 \mathrm{mg}, 0.42 \mathrm{mmol}$ ) and triethylamine (TEA, $85 \mathrm{mg}, 0.84 \mathrm{mmol}$ ) was stirred in $4 \mathrm{~mL}$ $\mathrm{DMF}$ at $25^{\circ} \mathrm{C}$ for $2 \mathrm{~h}$. The solution was poured into water and extracted with EtOAc, the organic layer was combined, washed with water and brine, and concentrated under reduced pressure to give the rude product. The product was purified by silica gel chromatography (DCM: $\mathrm{MeOH}=100: 2)$ as red solid, yield: $43 \% .{ }^{1} \mathrm{H}$ NMR $(600 \mathrm{MHz}$, DMSO$\left.d_{6}\right): \delta 8.86(\mathrm{~s}, 1 \mathrm{H}), 8.55(\mathrm{~s}, 1 \mathrm{H}), 7.66-7.71(\mathrm{~m}, 1 \mathrm{H}), 7.17-7.33(\mathrm{~m}, 5 \mathrm{H})$, 7.06-7.09 $(\mathrm{m}, 1 \mathrm{H}), 6.65-6.69(\mathrm{~m}, 2 \mathrm{H}), 6.34-$ $6.40(\mathrm{~m}, 1 \mathrm{H}), 6.15(\mathrm{~s}, 1 \mathrm{H}), 4.29-4.61(\mathrm{~m}, 4 \mathrm{H}), 3.90-4.02(\mathrm{~m}, 1 \mathrm{H}), 3.07-3.17(\mathrm{~m}, 1 \mathrm{H}), 2.61-2.72(\mathrm{~m}, 1 \mathrm{H}), 1.82-2.10$ $(\mathrm{m}, 1 \mathrm{H}), 1.68(\mathrm{~d}, 1 \mathrm{H}, J=10.7 \mathrm{~Hz}), 1.45-1.49(\mathrm{~m}, 2 \mathrm{H}) .{ }^{13} \mathrm{C}$ NMR $(150 \mathrm{MHz}$, DMSO-d 6 ): $\delta 165.27,162.59,160.06$, 159.94, 158.43, 158.31, 145.68, 145.13, 144.77, 144.43, 138.20, 133.72, 130.75, 129.63, 128.01, 127.81, 124.62, 124.56, $118.07,116.40,116.25,116.16,115.20,61.53,51.91,44.12,41.90,41.82,29.92,29.55,29.48$. HR-MS (ESI) [M+H] ${ }^{+}$ calculated for $\mathrm{C}_{27} \mathrm{H}_{24} \mathrm{FN}_{7} \mathrm{O}_{5}, 546.1896$; found: 546.1890 .<smiles>O=C(CCNc1ccc([N+](=O)[O-])c2nonc12)N1CCC(N2C(=O)c3ccccc3NC2c2ccccc2F)CC1</smiles>

2-(2-Fluorophenyl)-3-(1-(3-((7-nitrobenzo[c] $][1,2,5]$ oxadiazol-4-yl)amino)propanoyl)piperidin -4-yl)-2,3dihydroquinazolin-4(1H)-one (Probe 2$)$

Probe $\mathbf{2}$ was prepared from compound $\mathbf{5}(53 \mathrm{mg}, 0.21 \mathrm{mmol})$ and $\mathbf{8}(70 \mathrm{mg}, 0.21 \mathrm{mmol})$ as red solid, yield: $53 \% .{ }^{1} \mathrm{H}$ 
NMR (600 MHz, DMSO-d $): \delta 9.34(\mathrm{~d}, 1 \mathrm{H}, J=18.9 \mathrm{~Hz}), 8.51(\mathrm{~s}, 1 \mathrm{H}), 7.69(\mathrm{~d}, 1 \mathrm{H}, J=7.5 \mathrm{~Hz}), 7.15-7.32(\mathrm{~m}, 5 \mathrm{H})$, 7.05-7.07 (m, 1H), 6.64-6.68 (m, 2H), 6.40-6.44 (m, 1H), $6.15(\mathrm{dd}, 1 \mathrm{H}, J=3.2,9.3 \mathrm{~Hz}), 4.36-4.55(\mathrm{~m}, 2 \mathrm{H}), 3.80-3.92$ $(\mathrm{m}, 1 \mathrm{H}), 3.67(\mathrm{~s}, 1 \mathrm{H}), 2.96-3.09(\mathrm{~m}, 1 \mathrm{H}), 2.74-2.83(\mathrm{~m}, 2 \mathrm{H}), 2.52-2.60(\mathrm{~m}, 1 \mathrm{H}), 1.80-1.96(\mathrm{~m}, 2 \mathrm{H}), 1.63(\mathrm{~d}, 1 \mathrm{H}, J=$ $12.0 \mathrm{~Hz}$ ), 1.18-1.45 (m, 2H). ${ }^{13} \mathrm{C}$ NMR (150 MHz, DMSO-d $): \delta 168.69,168.62,162.58,160.06,159.96,158.43$, $158.33,145.69,145.36,144.87,144.57$, 138.42, 133.70, 130.77, 130.71, 129.68, 129.60, 128.00, 127.83, 124.60, 118.03, $116.39,116.25,116.21,115.16,99.81,61.57,52.19,52.11,44.76,41.14,41.11,30.04,29.91,29.53,29.41$. HR-MS (ESI) $[\mathrm{M}+\mathrm{H}]^{+}$calculated for $\mathrm{C}_{28} \mathrm{H}_{26} \mathrm{FN}_{7} \mathrm{O}_{5}, 560.2052$; found: 560.2067 .<smiles>O=C(CCCNc1ccc([N+](=O)[O-])c2nonc12)N1CCC(N2C(=O)c3ccccc3NC2c2ccccc2F)CC1</smiles>

2-(2-Fluorophenyl)-3-(1-(4-((7-nitrobenzo[c] $[1,2,5]$ oxadiazol-4-yl)amino)butanoic)piperidin-4-yl)-2,3dihydroquinazolin-4(1H)-one (Probe 3)

Probe 3 was prepared from compound $6(56 \mathrm{mg}, 0.21 \mathrm{mmol})$ and $8(70 \mathrm{mg}, 0.21 \mathrm{mmol})$, and was purified by HPLC $(\mathrm{MeOH}: \mathrm{H} 2 \mathrm{O}=60: 40)$ as red solid, yield: $16 \% . \delta 8.47(\mathrm{~s}, 1 \mathrm{H}), 7.69(\mathrm{~d}, 1 \mathrm{H}, J=7.4 \mathrm{~Hz}), 7.15-7.32(\mathrm{~m}, 5 \mathrm{H}), 7.05-7.07$ $(\mathrm{t}, 1 \mathrm{H}, J=7.4 \mathrm{~Hz}), 6.64-6.68(\mathrm{~m}, 2 \mathrm{H}), 6.40(\mathrm{t}, 1 \mathrm{H}, J=9.8 \mathrm{~Hz}), 6.13-6.14(\mathrm{~m}, 1 \mathrm{H}), 4.37-4.52(\mathrm{~m}, 2 \mathrm{H}), 3.82-3.94(\mathrm{~m}$, $1 \mathrm{H}), 3.45-3.47(\mathrm{~m}, 2 \mathrm{H}), 2.95-3.06(\mathrm{~m}, 1 \mathrm{H}), 2.53-2.57(\mathrm{~m}, 1 \mathrm{H}), 2.40-2.48(\mathrm{~m}, 2 \mathrm{H}), 1.78-1.98(\mathrm{~m}, 3 \mathrm{H}), 1.63(\mathrm{~d}, 1 \mathrm{H}, J$ $=11.7 \mathrm{~Hz}), 1.16-1.47(\mathrm{~m}, 2 \mathrm{H}) .{ }^{13} \mathrm{C}$ NMR $\left(150 \mathrm{MHz}, \mathrm{DMSO}-d_{6}\right): \delta 170.36,162.58,160.05,159.96,158.42,158.33$, $146.04,145.69$, 145.20, 144.78, 138.04, 133.68, 130.71, 129.72, 129.63, 127.99, 127.82, 124.60, 120.53, 118.01, 116.39, $116.25,116.20$, 115.13, 99.80, 61.65, 52.36, 44.79, 43.94, 41.19, 41.14, 30.12, 30.01, 29.94, 29.57, 29.45, 23.91. HRMS (ESI) $[\mathrm{M}+\mathrm{H}]^{+}$calculated for $\mathrm{C}_{29} \mathrm{H}_{28} \mathrm{FN}_{7} \mathrm{O}_{5}, 574.2209$; found: 574.2220.

\section{Fluorescence Spectroscopy Test of Probes 1-3.}

Probes 1-3 were dissolved into DMSO and acquired a $10 \mathrm{mM}$ stocking solution, respectively. The stocking solution was diluted in PBS ( $\mathrm{pH}=7.4$ ) to get a $5 \mu \mathrm{M}$ final concentration solution. The fluorescent properties of probes 1-3 were tested by a BioTek microplate reader. We also assay the emission spectrum of probes 1-3 before and after adding PDE $\delta$ protein, $1 \mu \mathrm{M}$ probes 1-3 were dissolved in experimental buffer (PBS, $\mathrm{pH}=7.4$, contained $0.05 \%$ chaps and $0.1 \%$ Tween $80)$ with different concentration of $\mathrm{PDE} \delta$ protein $(0-2 \mu \mathrm{M})$ at room temperature for $30 \mathrm{~min}$, then scanned the emission spectrum by F-7000 fluorescent spectrometer according to the excitation wavelength of probes 1-3. The quantum yields of probes 1-3 were measured under PBS buffer solution $(\mathrm{pH}=7.4)$ and DMSO, respectively. The fluorescein $0.1 \mathrm{M} \mathrm{NaOH}\left(\Phi_{\mathrm{ST}}=0.92\right)$ was set as a reference. The quantum yields were calculated by the following equation: $\Phi_{\mathrm{X}}=$ $\Phi_{\text {ST }}\left(\mathrm{A}_{\mathrm{ST}} / \mathrm{A}_{\mathrm{X}}\right)\left(\mathrm{F}_{\mathrm{X}} / \mathrm{F}_{\mathrm{ST}}\right)\left(\eta_{\mathrm{X}} / \mathrm{\eta}_{\mathrm{ST}}\right)^{2}$.

Where the subscripts ST and X denote standard and test respectively, $\Phi$ is the quantum yield, $\mathrm{F}$ is the integrated area under the fluorescence spectra, $A$ is the absorbance, $\eta$ is the refractive index of the solvent.
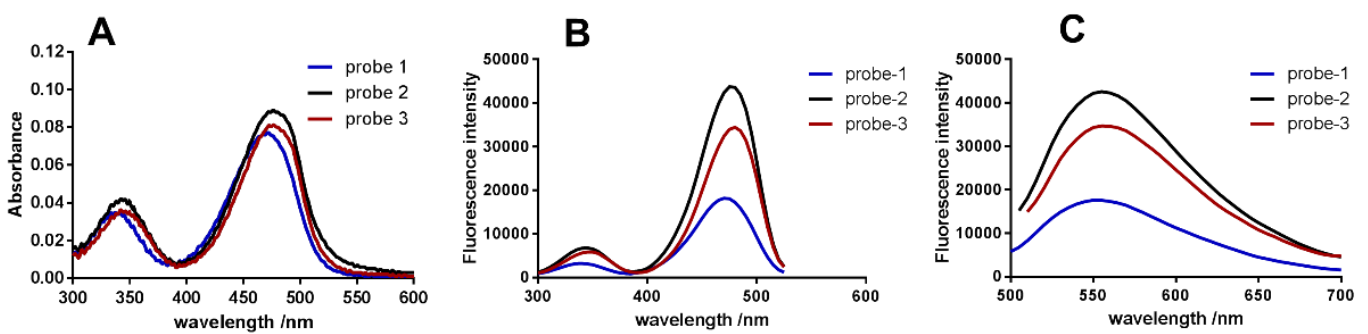
Figure S1 (A) Absorption spectra of probes 1-3; (B) fluorescence excitation spectrum and (C) fluorescence emission spectrum.

\section{The Effect of Probes 1-3 to the FP Assay.}

The fluorescence polarization (FP) assay as described previously reports. ${ }^{2}$ FP value changes of probes 1-3 (100 nM) with different concentration of $\mathrm{PDE} \mathcal{\delta}$ protein using the FP assay. The following values are read for automatic sensitivity.

Table S1. The effect of probes 1-3 to the fluorescence polarization assay

\begin{tabular}{rllll}
\hline PDE $\delta(\mu \mathrm{M})$ & 0.81 & 0.27 & 0.09 & 0.03 \\
\hline Probe 1 & 132.7 & 133.5 & 133.2 & 142.8 \\
Probe 2 & 113.7 & 114.2 & 120.8 & 144.5 \\
Probe 3 & 118.0 & 114.0 & 128.5 & 134.0 \\
\hline
\end{tabular}

Fluorescence Anisotropy Assay.

Determination of equilibrium dissociation constants $K_{\mathrm{D} 2}$ for each compound was performed using the fluorescence anisotropy assay with Atrovastatin-PEG3-FITC reference previous reports. ${ }^{1,3}$ PDE $\delta$ protein at $160 \mathrm{nM}$ and Atrovastatin-PEG3-FITC at $100 \mathrm{nM}$ were mixed with $100 \mu \mathrm{L}$ PBS-buffer (containing 0.05\% Chaps, 0.5\% DMSO) in 96-well flat-bottom black plates (Corning \# 3650). A 3-fold serial dilution of each compound ( $100 \mu \mathrm{L}$ ) containing $0.5 \%$ DMSO was added to the solution. The fluorescence anisotropy was measured after $3 \mathrm{~h}$ incubation at $30^{\circ} \mathrm{C}$ on Biotek Synergy $\mathrm{H} 2$ with the $485 \mathrm{~nm}$ excitation and $535 \mathrm{~nm}$ emission filters. The $\mathrm{K}_{\mathrm{D} 2}$ of each compound was calculated by fitting the displacement curves to the following equations using Mathematica (Wolfram Mathematica 9, Wolfram Research Inc.)

$$
\begin{aligned}
& d=K_{D 1}+K_{D}+L_{S T}+L_{T}-R_{T} ; \\
& e=\left(L_{T}-R_{T}\right) \times K_{D 1}+\left(L_{S T}-R_{T}\right) \times K_{D}+K_{D 1} \times K_{D} ; \\
& f=-K_{D 1} \times K_{D} \times R_{T} ; \\
& \theta=\operatorname{ArcCoS}\left[\frac{-2 \times d^{3}+9 \times d \times e-27 f}{2 \times \sqrt{\left(d^{2}-3 \times e\right)^{3}}}\right] \\
& F=\frac{2 \times\left(\sqrt{\left.d^{2}-3 \times e\right) \times \operatorname{CoS}\left[\frac{\theta}{3}\right]-d}\right.}{3 \times K_{D 1}+2 \times\left(\sqrt{d^{2}-3 \times e}\right) \times \operatorname{Cos}\left[\frac{\theta}{3}\right]-d} \\
& A=\frac{Q \times F \times A_{B}+(1-F) \times A_{F}}{1-(1-Q) \times F}
\end{aligned}
$$

In these equations, $A_{B}$ and $A_{F}$ represent the anisotropies of bound and free probe, $K_{\mathrm{D} 1}$ is the equilibrium dissociation constant of the fluorescent probe (Figure S2), $Q$ is the ratio of the fluorescence intensity of the probe in the bound and free status, $\mathrm{F}_{S B}$ is the fraction of bound probe, $\mathrm{R}_{\mathrm{T}}$ is the receptor protein concentration, $\mathrm{L}_{S \mathrm{~T}}$ is the concentration of probe, $\mathrm{L}_{\mathrm{T}}$ is total concentration of unlabeled small molecule competitor, $K_{\mathrm{D} 2}$ is the dissociation constant of the test compound. 


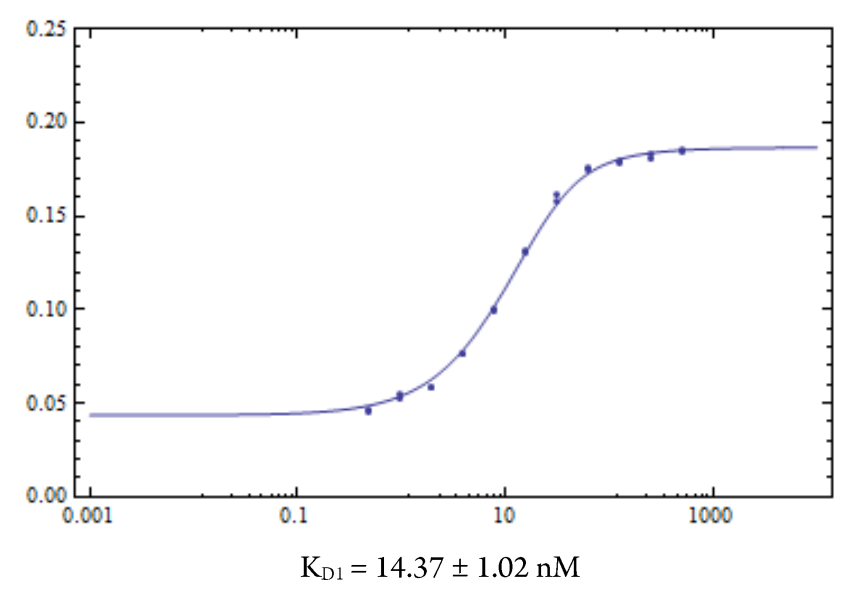

Figure S2. The $\mathrm{K}_{\mathrm{D} 1}$ curve of Atrovastatin-PEG3-FITC and PDE $\delta$ protein

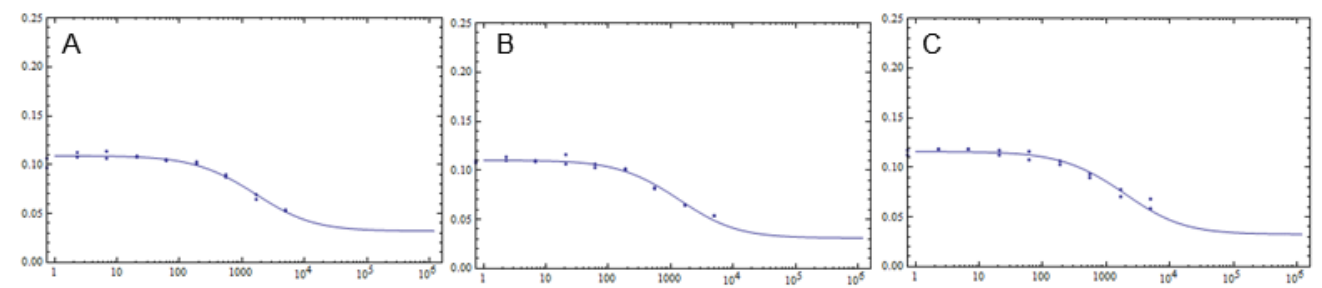

Figure S3. Competitive binding curves of probes 1-3 to PDE $\delta$. A: probe 1; B: probe 2; C: probe 3.

\section{In Vitro Antiproliferative Assay of Probes 1-3}

The cellular growth inhibitory activity of probes was determined by CCK-8 assays, MIA PaCa-2, Capan-1 and A549 cell lines were chosen to test the antiproliferative assay of probes 1-3. Following the instruction of manufacturer's protocol, $5 \times 10^{3}$ cells per well were placed in 96-well transparent plates with $100 \mu \mathrm{L}$ culture medium and then cultured $37^{\circ} \mathrm{C}$ in a humidified $5 \% \mathrm{CO}_{2}$ atmosphere overnight. Subsequently, probes or deltazinone were added to the wells at different concentrations, and then incubated for $48 \mathrm{~h}$. Then, each well was added with $10 \mu \mathrm{L} \mathrm{CCK}-8$ working solution according to the protocol of manufacturer, the absorbance value of each well was recorded using a microplate reader at $450 \mathrm{~nm}$. A well without any compound was set as the blank. The concentration of each probe that inhibited cell growth by $50 \%$ (IC $\mathrm{I}_{50}$ ) was calculated by GraphPad Prism 5 software.

Table S2. Biological data of probes 1-3 and deltazinone

\begin{tabular}{ccccc}
\hline compound & $\boldsymbol{K}_{\mathbf{D} 2}(\mathbf{n M})$ & $\begin{array}{c}\text { Capan-1 } \\
\left(\mathbf{I} \mathbf{C}_{\mathbf{5 0}}\right)(\boldsymbol{\mu M})\end{array}$ & $\begin{array}{c}\text { MIA PaCa-2 } \\
\left(\mathbf{I C}_{\mathbf{5 0}}\right)(\boldsymbol{\mu M})\end{array}$ & $\begin{array}{c}\mathbf{A 5 4 9} \\
\left(\mathbf{I C}_{\mathbf{5 0}}\right)(\boldsymbol{\mu M})\end{array}$ \\
\hline Probe 1 & $682 \pm 91$ & $43.4 \pm 8.83$ & $37.7 \pm 4.18$ & $>100$ \\
Probe 2 & $440 \pm 73$ & $30.9 \pm 7.88$ & $24.7 \pm 4.48$ & $>100$ \\
Probe 3 & $501 \pm 82$ & $33.4 \pm 8.25$ & $15.9 \pm 1.28$ & $42.8 \pm 5.89$ \\
deltazinone & $1.06 \pm 0.55$ & $35.3 \pm 1.54$ & $61.6 \pm 4.07$ & $>100$ \\
\hline
\end{tabular}

Fluorescence Microscopy Imaging.

Cell Culture. MIA-PaCa-2, Capan-1 cell line was chosen as the living cell to evaluate the fluorescent properties of probe 1-3. HEK-293 cell line was set as the negative control. They were cultured in DMEM (high glucose, Hyclone) with $10 \%$ 
(v/v) fetal bovine serum and $100 \mathrm{U} / \mathrm{ml}$ penicillin, $0.1 \mathrm{mg} / \mathrm{ml}$ streptomycin (Biological Industries) at $37^{\circ} \mathrm{C}$ in a humidified $5 \% \mathrm{CO}_{2}$ atmosphere, respectively. When the cells were in the proliferation period, these two types of cells were transferred to the confocal dish and cultured overnight.

Staining. Remove the old culture medium out of the confocal dish, and then use DMEM medium free fetal bovine serum wash the cells carefully and incubated at $37^{\circ} \mathrm{C}$ in a humidified $5 \% \mathrm{CO}_{2}$ atmosphere. Probe 1-3 were dissolved in DMSO to get a stock solution $(10 \mathrm{mM})$. Then, the probes were further diluted with DMEM medium free fetal bovine serum at a final concentration of $5 \mu \mathrm{M}$ and co-staining with the nuclear dye $500 \mathrm{nM}$ Hoechst 33342. Subsequently, MIA PaCa-2, Capan-1 and HEK-293 cells incubate with probe 1-3 at $37^{\circ} \mathrm{C}$ for $15 \mathrm{~min}$, respectively.

MIA PaCa-2 and Capan-1 cells were also incubated with KRAS-PDE $\delta$ inhibitor (100 $\mu \mathrm{M}$ deltazinone) and $5 \mu \mathrm{M}$ each probe as the positive control at the same conditions.

Fluorescence Imaging. Fluorescence imaging in living MIA PaCa-2, Capan-1 and HEK-293 cell lines were captured by the Zeiss Axio Observer A1 fluorescent microscope. Objective lens: 63x.

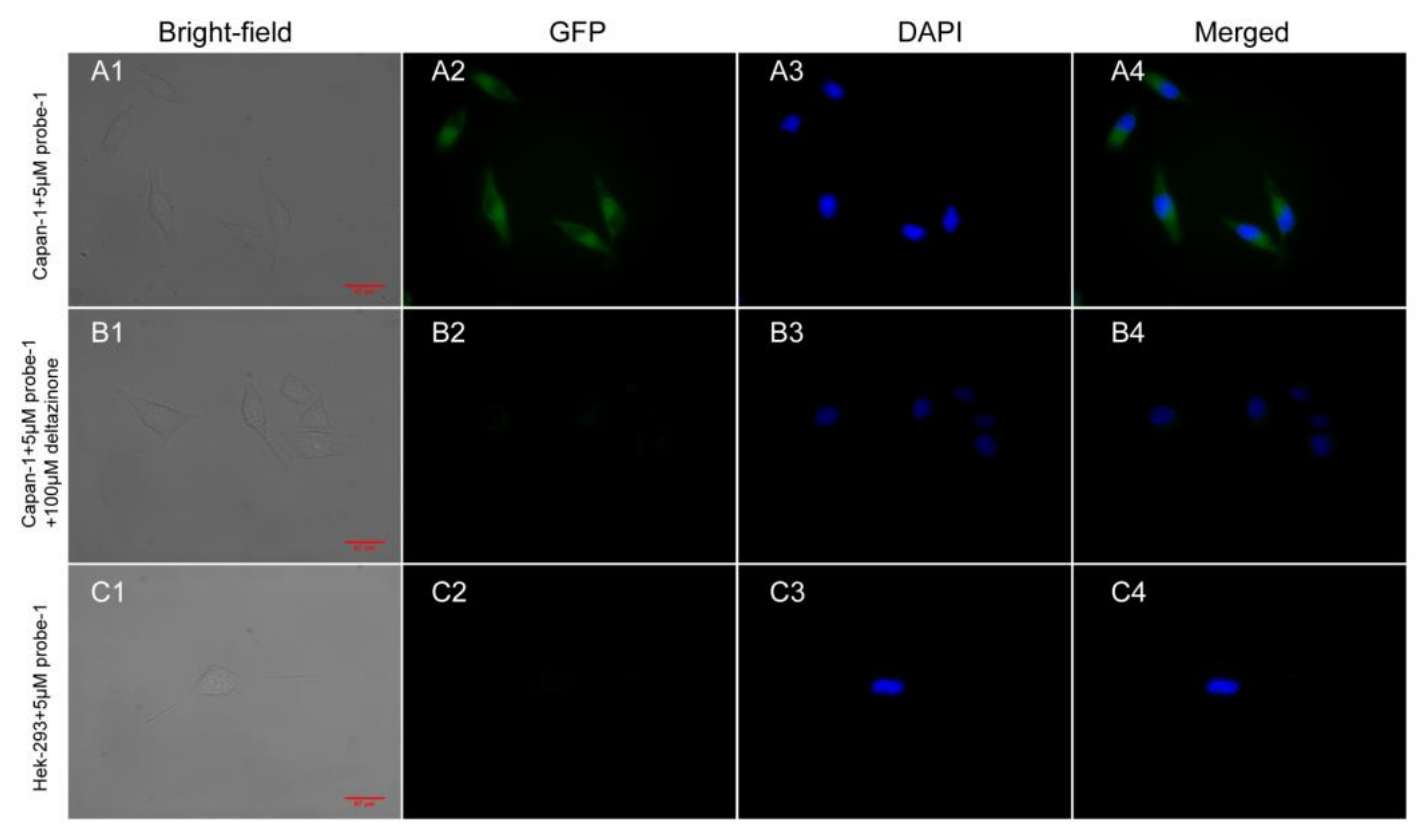

Figure S4. Fluorescence microscopic imaging of Capan-1 cells and HEK 293 cells incubated with $5 \mu \mathrm{M}$ probe $\mathbf{1}$ (A1, B1 and C1-bright field; A2, B2 and C2-GFP channel; A3, B3 and C3-DAPI channel; A4, B4 and C4 are the merged images). A: Capan-1 cells incubated with $5 \mu \mathrm{M}$ probe 1; B: Capan-1 cells co-incubated with $5 \mu \mathrm{M}$ probe 1 and $100 \mu \mathrm{M}$ deltazinone; C: HEK 293 cells incubated with $5 \mu \mathrm{M}$ probe 1 . The backgrounds of all the images were adjusted by Image J software. The imaging was performed using a Zeiss Axio Observer A1 microscope with a $63 \times$ objective lens. Scale bar $=67 \mu \mathrm{m}$. 


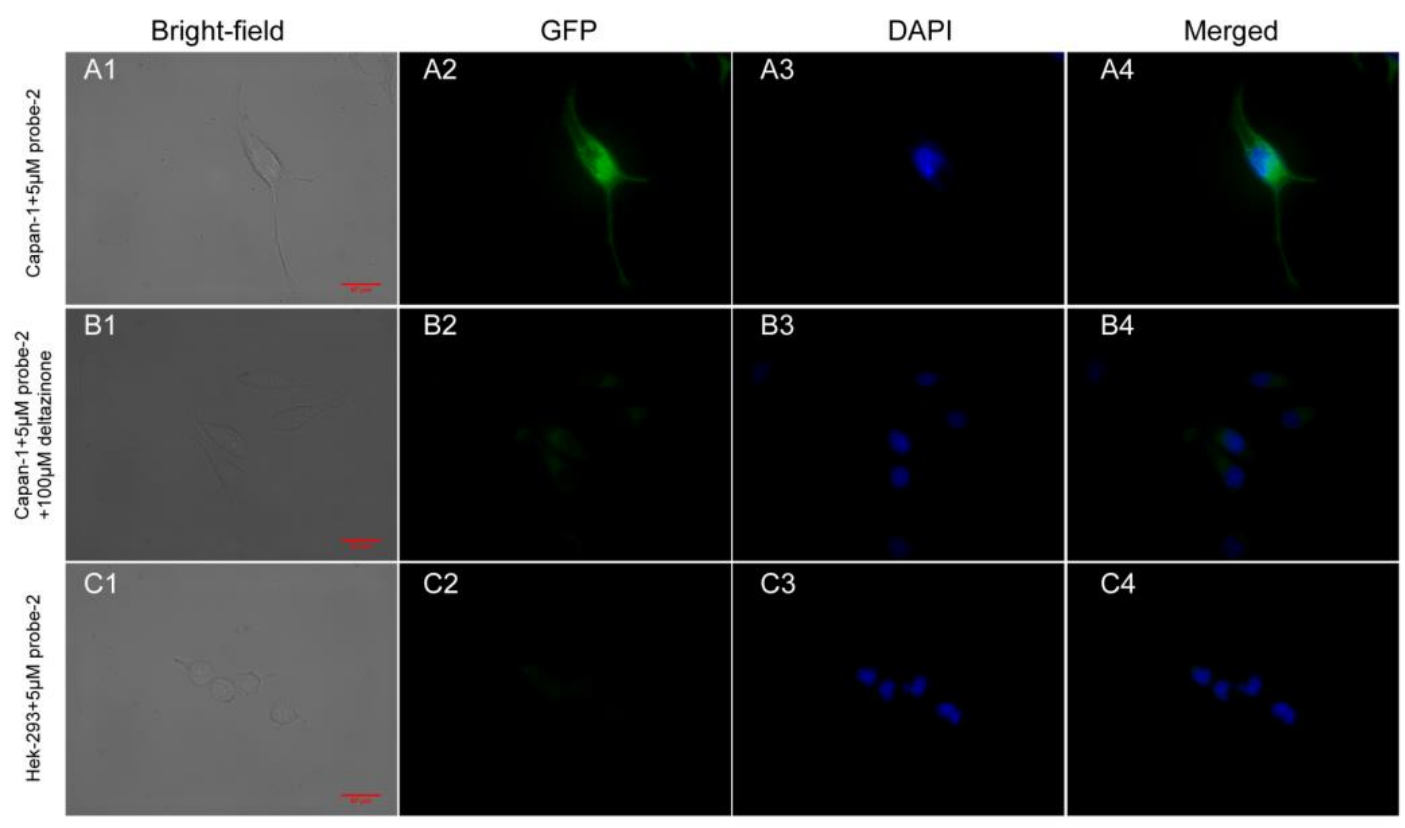

Figure S5. Fluorescence microscopic imaging of Capan-1 cells and HEK 293 cells incubated with $5 \mu \mathrm{M}$ probe 2 (A1, B1 and C1-bright field; A2, B2 and C2-GFP channel; A3, B3 and C3-DAPI channel; A4, B4 and C4 are the merged images). A: Capan-1 cells incubated with $5 \mu \mathrm{M}$ probe 2; B: Capan-1 cells co-incubated with $5 \mu \mathrm{M}$ probe 2 and $100 \mu \mathrm{M}$ deltazinone; C: HEK 293 cells incubated with $5 \mu \mathrm{M}$ probe 2 . The backgrounds of all the images were adjusted by Image J software. The imaging was performed using a Zeiss Axio Observer A1 microscope with a $63 \times$ objective lens. Scale bar $=67 \mu \mathrm{m}$.

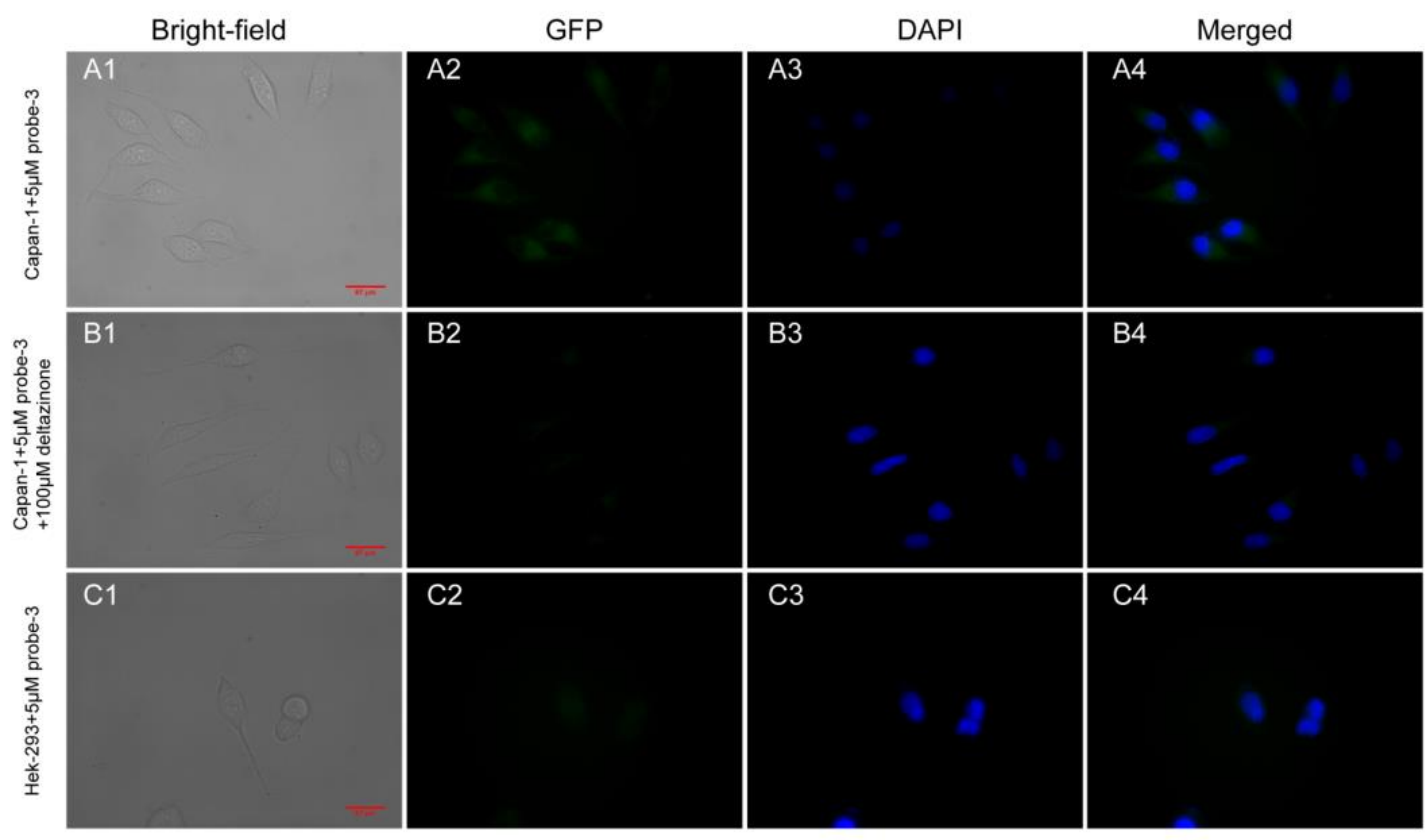

Figure S6. Fluorescence microscopic imaging of Capan-1 cells and HEK 293 cells incubated with $5 \mu \mathrm{M}$ probe 3 (A1, B1 and C1-bright field; A2, B2 and C2-GFP channel; A3, B3 and C3-DAPI channel; A4, B4 and C4 are the merged images). A: Capan-1 cells incubated with $5 \mu \mathrm{M}$ probe 3; B: Capan-1 cells co-incubated with $5 \mu \mathrm{M}$ probe 3 and $100 \mu \mathrm{M}$ deltazinone; C: HEK 293 cells incubated with $5 \mu \mathrm{M}$ probe 3 The backgrounds of all the images were adjusted by Image J software. The imaging was performed using a Zeiss Axio Observer A1 microscope with a $63 \times$ objective lens. Scale bar $=67 \mu \mathrm{m}$. 


\section{Flow Cytometry Analysis.}

The flow cytometry test was performed on Capan- 1 cell line. Cells were collected and washed by $1 \times$ PBS for three times. Each flow tubes with $1 \times 10^{5}$ cells in $300 \mu \mathrm{L}$ PBS, and probes 1-3 was added at a final concentration of $5 \mu \mathrm{M}$, respectively. We also set Capan- 1 cell co-incubated with probes and $100 \mu \mathrm{M}$ deltazinone; the Capan- 1 cells incubated with $100 \mu \mathrm{M}$ deltazinone was also set as the positive control. After incubated for about $30 \mathrm{~min}$ at $37^{\circ} \mathrm{C}$ atmosphere, the samples were analyzed by the Beckman CytoFLEX Cell Counter.
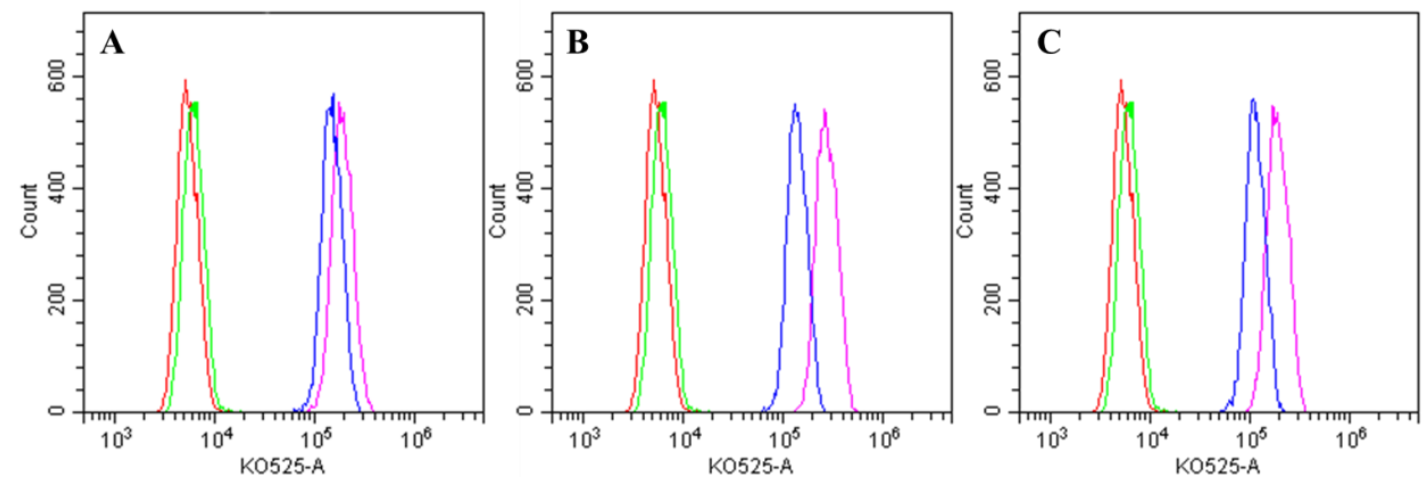

Figure S7. Flow cytometry test results of $5 \mu \mathrm{M}$ probes 1-3 and $100 \mu \mathrm{M}$ deltazinone binding to the Capan-1 living cells, respectively (red-blank; green-deltazinone; violet -probes; blue-probes with deltazinone). A: Probe 1, B: Probe 2, C: Probe 3.

Total RNA Preparation, cDNA Synthesis, and quantitative Real-time PCR

The MIA PaCa-2 and Capan-1 cells were treated with $10 \mu \mathrm{M}$ probe 1-3 for $4 \mathrm{~h}$. Total RNA was extracted by RNAiso Plus following the instructions of the manufacturer (Takara BIO INC. Dalian, China). The total RNA was quantitative by the microplate reader. The First-stand cDNA was synthesized follow the process: $1.5 \mu \mathrm{g}$ RNA was reversed transcription to cDNA with HiFiscript cDNA synthesis kit (CWBIO, CW2569M, Beijing, China), following the manufacturer's instructions. The cDNA was stored at $-20^{\circ} \mathrm{C}$ until use. the real-time PCR at a final volume of $10 \mu \mathrm{L}$, included $5 \mu \mathrm{L}$ of $2 \times$ FastStart Universal SYBR Green Master (ROX) (Roche, Switzerland), $1 \mu \mathrm{L}$ of cDNA solution, 0.1 $\mu \mathrm{L}$ of forward primers, $0.1 \mu \mathrm{L}$ of reverse primers and $3.8 \mu \mathrm{L}$ of deionized water. And followed the cycle parameters recommended by the manufacturer of Roche: Preincubation at $95{ }^{\circ} \mathrm{C}$ for $10 \mathrm{~min}$, followed by 50 cycles of two steps amplification: $95^{\circ} \mathrm{C}$ for $10 \mathrm{~s}, 60^{\circ} \mathrm{C}$ for $30 \mathrm{~s}$, and then with a Melting curve. Quantitative real-time PCR performed by the Roche PCR system (LightCycler 96 SW 1.1), all the cDNA samples were performed in triplicate with each primer. The relative expression levels of KRAS and PDE $\delta$ were calculated by the $2^{-\triangle \Delta C T}$ method.

Table S3. The primers for $\mathrm{qPCR}$

\begin{tabular}{ccc}
\hline Gene & Forward primer $\left(5^{\prime}-3^{\prime}\right)$ & Reverse primer $\left(5^{\prime}-3^{\prime}\right)$ \\
\hline GAPDH & GAAGGTGAAGGTCGGAGT & CATGGGTGGAATCATATTGGAA \\
KRAS & CAGTAGACACAAAACAGGCTCAG & TGTCGGATCTCCCTCACCAATG \\
PDE $\delta$ & TCCGCCTGGAACAAAAAGTT & TCGGGTGCTGCCTCTATCA \\
MAPK1 & ACACCAACCTCTCGTACATCGG & TGGCAGTAGGTCTGGTGCTCAA \\
AKT1 & TGGACTACCTGCACTCGGAGAA & GTGCCGCAAAAGGTCTTCATGG \\
RAF1 & TCAGGAATGAGGTGGCTGTTCTG & CTCGCACCACTGGGTCACAATT \\
MEK7 & GACCTGGATGTGGTGCTGAAGA & TCTTGAGCTTCTCAGCGCAGGT \\
mTOR & AGCATCGGATGCTTAGGAGTGG & CAGCCAGTCATCTTTGGAGACC \\
\hline
\end{tabular}



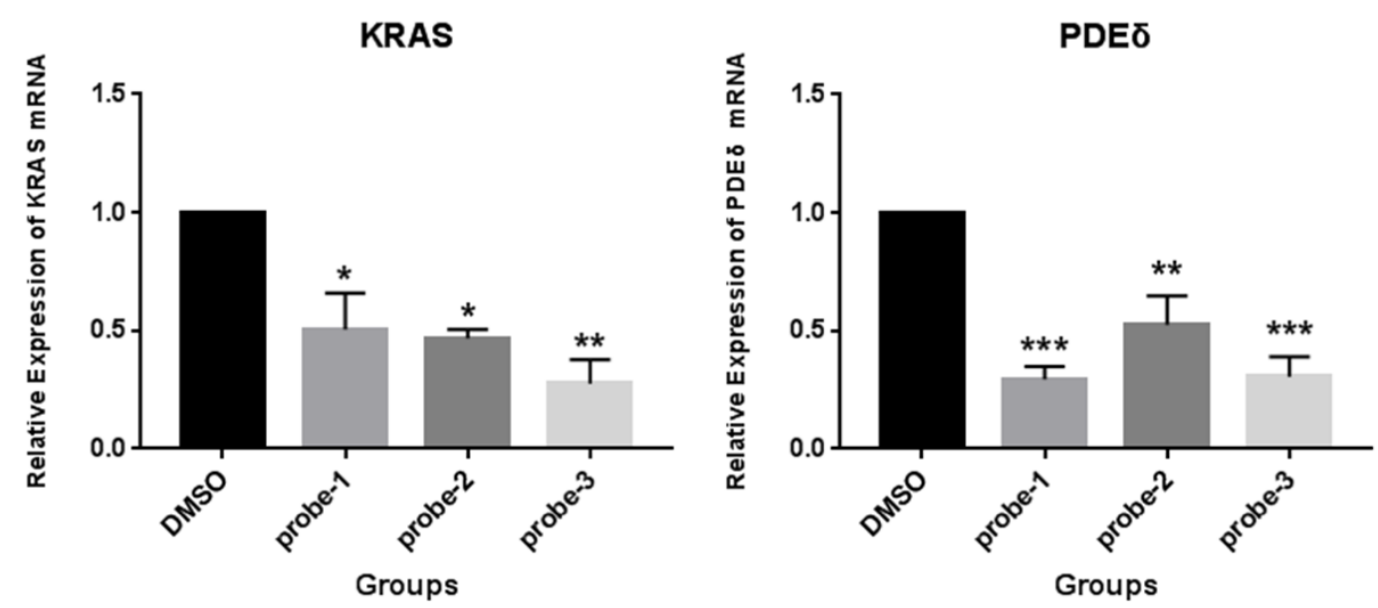

Figure S8. The relative mRNA expression of KRAS and PDE $\delta$ by real-time PCR in Capan-1 cell line. KRAS and PDE $\delta$ were down regulated by probes 1-3 $(10 \mu \mathrm{M})$, all values were expressed as mean values \pm SEM. Data were analyzed by one-way ANOVA, ${ }^{*} p<0.05, \stackrel{* *}{p}<0.01,{ }^{* * *} p<0.001 v$ s. DMSO group.

\section{Western Blot.}

Mia PaCa-2 cells were seeded at a density of $5 \times 10^{5}$ each well in 6-well plates. After $24 \mathrm{~h}$ incubation, cells were stimulated with $125 \mathrm{ng} / \mathrm{ml}$ EGF for $5 \mathrm{~min}$ and then treated with various concentrations of compounds for $2 \mathrm{~h}$. Briefly, add appropriate amount of ice-cold lysis buffer containing protease inhibitor (Sigma) and phosphatase inhibitor I and II (Sigma) to each plate well. Scraped off on ice and shake gently for $15 \mathrm{~min}$. Collect the lysate, transfer to a microcentrifuge tube and centrifugate at $4{ }^{\circ} \mathrm{C}, 12,000 \mathrm{~g}$ for $15 \mathrm{~min}$. The extracted protein was denatured on boiling water. $30 \mu \mathrm{g}$ protein samples from each lysate were separated by SDS-PAGE, transferred to $0.45 \mu \mathrm{m}$ PVDF membranes and blocked with blocking buffer (5\% BSA in TBST) at room temperature for $2 \mathrm{~h}$. The membranes were then incubated with primary antibodies against PDE $\mathcal{S}$ (Santa Cruz \#sc-376724, 1:100), p44/42 MAPK (Erk1/2) (abcam \#17942, 1:1000), Phospho-p44/42 MAPK (Erk1/2) (Thr202/Tyr204) (Cell Signaling Technology\#9101, 1:1000), Akt (pan) (C67E7) (Cell Signaling Technology \#4691, 1:1000), Phospho-Akt (Ser473) (Cell Signaling Technology \# 4060, 1:1000) and GAPDH (Affinity \#AF7021, 1:800) at $4{ }^{\circ} \mathrm{C}$ overnight, and finally incubated with goat-anti-rabbit IgG (Abcam \#216777, 1:5000) or goat-anti-mouse IgG (Abcam \#216776, 1:5000) secondary FITC-labeled antibodies for $2 \mathrm{~h}$ in the dark. PVDF membranes were scanned by ChemiDoc XRS imaging system (Bio-Rad, Hercules, CA). To quantify the protein levels, gray values of the bands was calculated with the control group using as the standard in the resulting images.

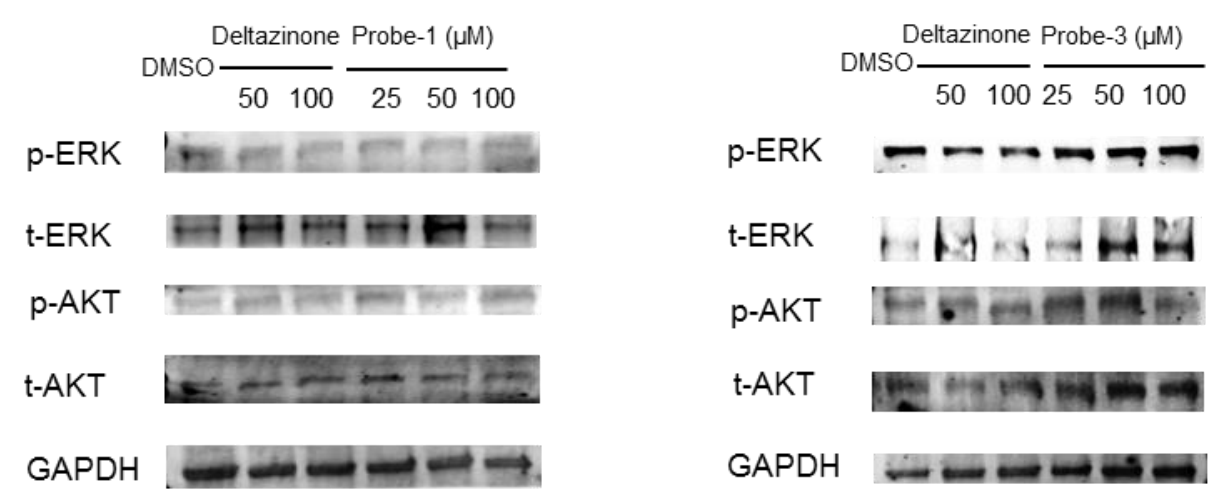

Figure S9. Protein expression level detected by Western Blot after treated by probe $\mathbf{1}$ and probe 3 (MIA PaCa-2 cell 
lines)

\section{Immunohistochemical Analysis of Paraffin Embedded Capan-1.}

According to the protocol of Immunohistochemistry, the Capan-1 tumor, HeLa tumor and the normal skin of forelimb armpit of BALB/c nude mice tissue were harvested. after formalin-fixed and then paraffin embedded, the tumors were sectioned into $3 \mu \mathrm{m}$ thickness layers., tissue slices were deparaffinized in xylene, then rehydration in graded alcohols, after antigen repaired by the All-purpose Powerful Antigen Retrieval Solution (Beyotime Biotechnology, P0088, Shanghai, China) at $95-100{ }^{\circ} \mathrm{C}$ for $20 \mathrm{~min}$, the slices were incubation with primary antibodies Anti-KRAS antibody (1:150, Catalog Number: 12063-1-AP, Proteintech) overnight at $4{ }^{\circ} \mathrm{C}$. And then were incubated with secondary antibody goat anti-mouse Ig G and goat antibody rabbit Ig G polymer (Gene Tech, GK600505, Shanghai, China) at room temperature for $15 \mathrm{~min}$, followed by staining with $\mathrm{DAB}$ at room temperature for $2 \mathrm{~min}$. Finally, tumor slices were washed and counterstained with hematoxylin. After dehydration by gradient ethanol, the slices were mounted under cover slips by neutral gum. The slices were captured by the OLYMPUS VS120. Objective lens: 40x.

\section{Imaging Analysis of Paraffin Embedded Capan-1 and HeLa Tumor Slices.}

The stock solution $(10 \mathrm{mM})$ of probes was diluted in Krebs buffer $(\mathrm{pH}=7.4)$ to obtain a $10 \mu \mathrm{M}$ final concentration solutions. The Capan-1 tumor, HeLa tumor and the normal skin of forelimb armpit of BALB/c nude mice tissue were sectioned into many $3 \mu \mathrm{m}$ thickness layers. Tissue slices were deparaffinized in xylene before rehydration in graded alcohols, after antigen repaired by the All-purpose Powerful Antigen Retrieval Solution (Beyotime Biotechnology, P0088, Shanghai, China) at $95-100{ }^{\circ} \mathrm{C}$ for $20 \mathrm{~min}$, the slices were incubation with probes 1-3 overnight at $4{ }^{\circ} \mathrm{C}$, respectively. Then use the Krebs buffer washed several times. Finally, the slices were mounted under cover slips by neutral gum. Then all the slices were captured by the OLYMPUS VS120 virtual slide microscope. Objective lens: 40X. The Capan-1 tumor slices were also incubated with $200 \mu \mathrm{M}$ deltazinone and $10 \mu \mathrm{M}$ each probe at the same conditions. Then all the slices were captured by the OLYMPUS VS120 virtual slide microscope. Objective lens: 40x. 
NMR and HRMS Spectra of Probes 1-3

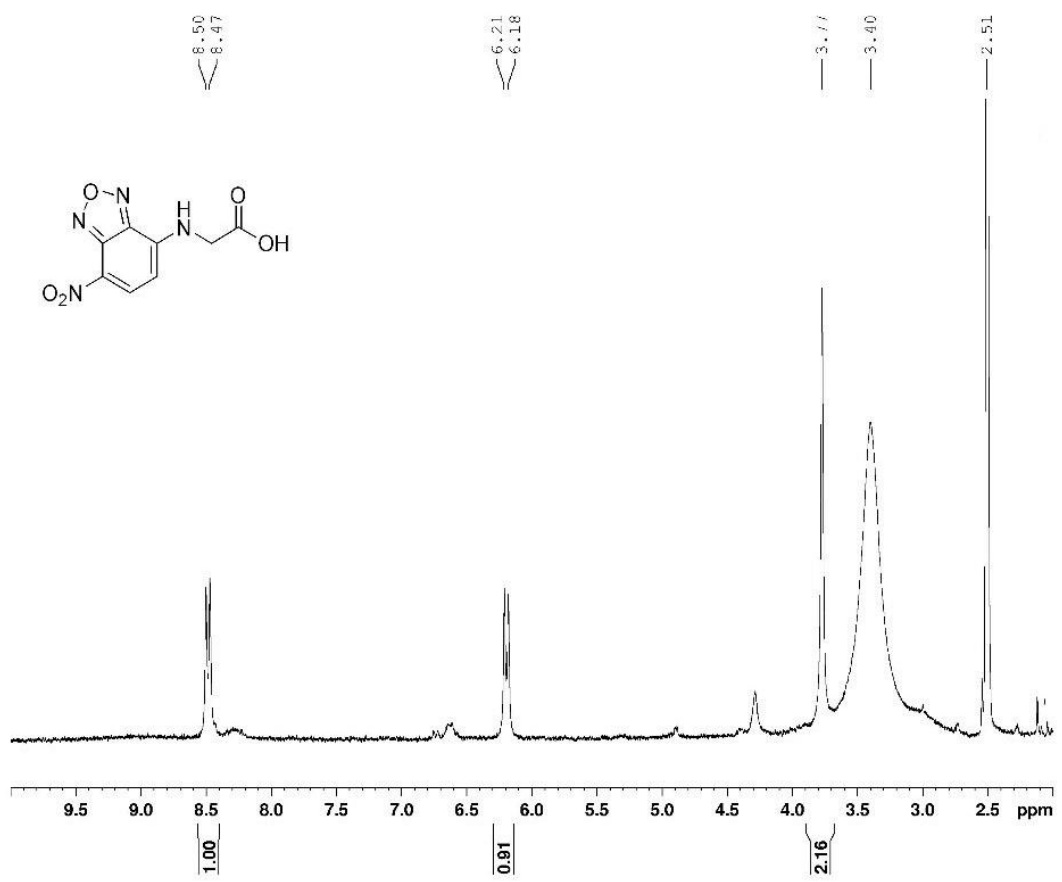

Figure S10. ${ }^{1} \mathrm{H}$ NMR spectrum of compound 4.

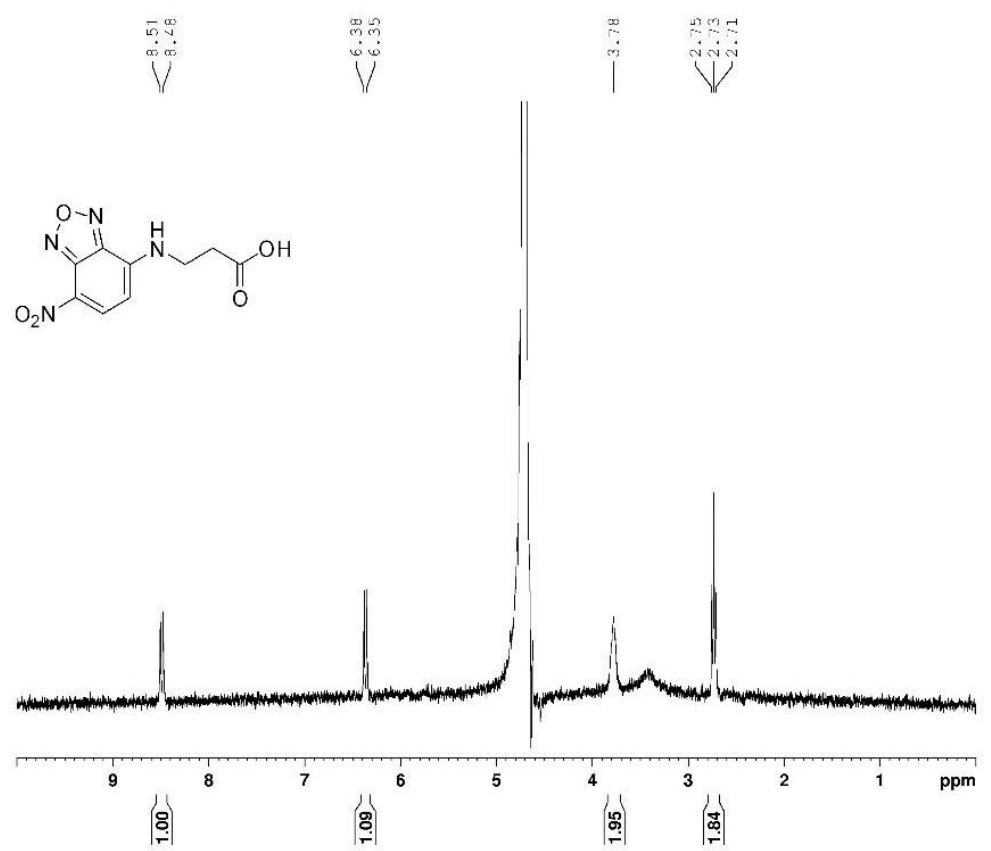

Figure S11. ${ }^{1} \mathrm{H}$ NMR spectrum of compound 5. 


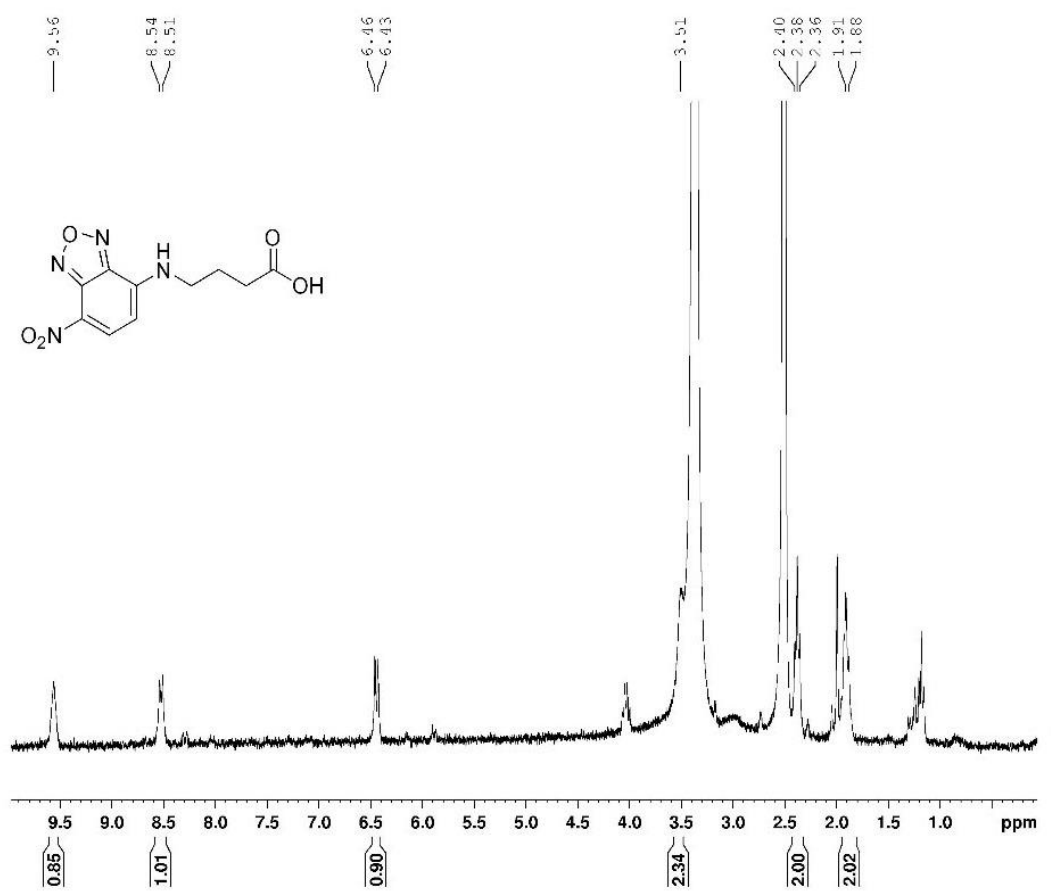

Figure S12. ${ }^{1} \mathrm{H}$ NMR spectrum of compound 6 .

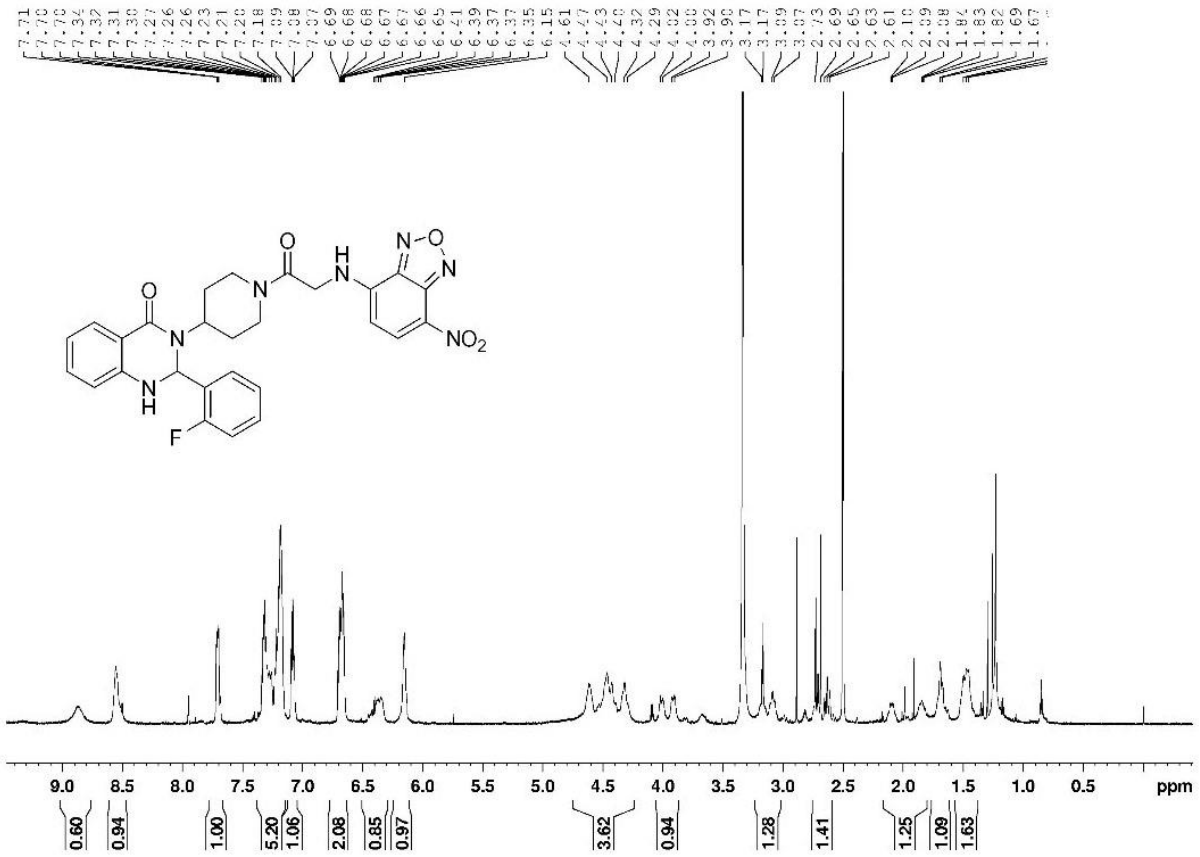

Figure S13. ${ }^{1} \mathrm{H}$ NMR spectrum of probe-1. 


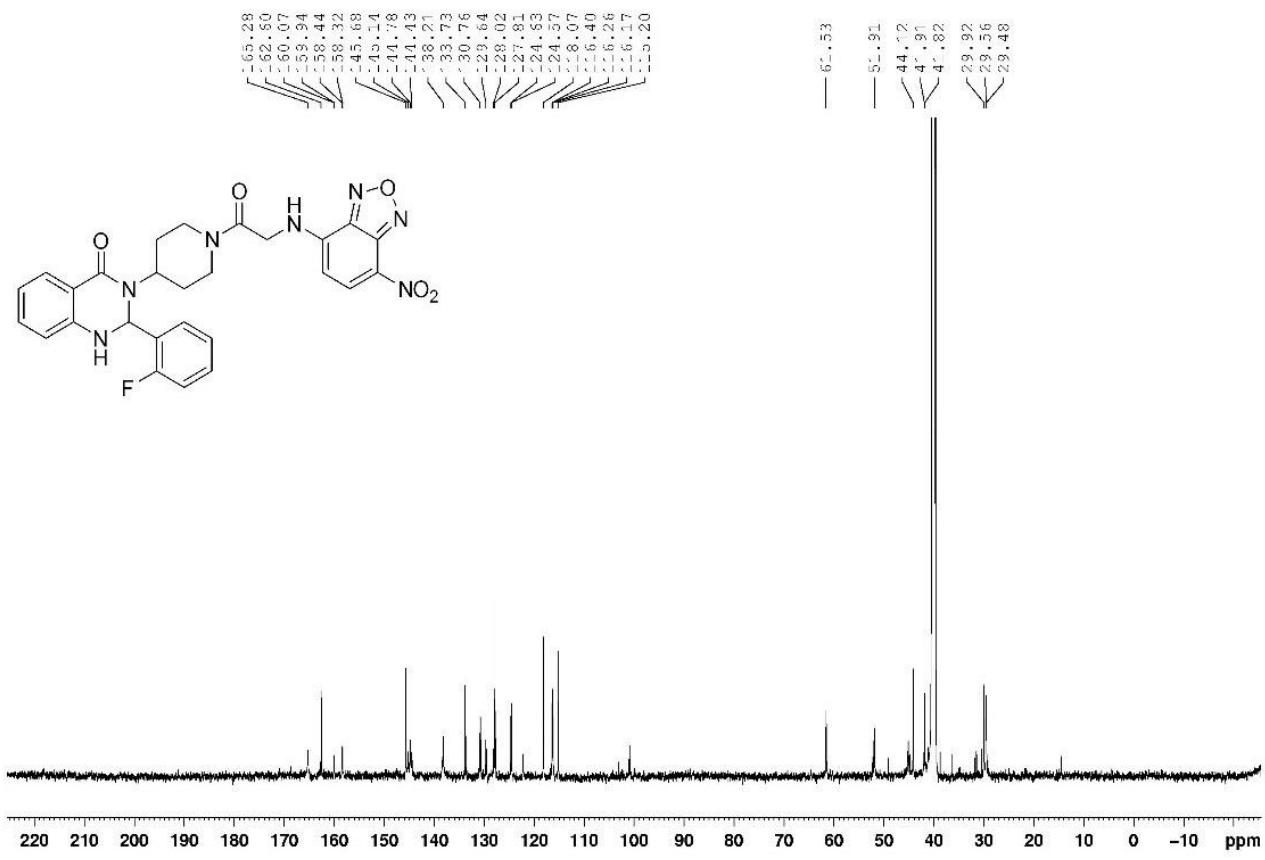

Figure S14. ${ }^{13} \mathrm{C}-\mathrm{NMR}$ spectrum of probe-1.

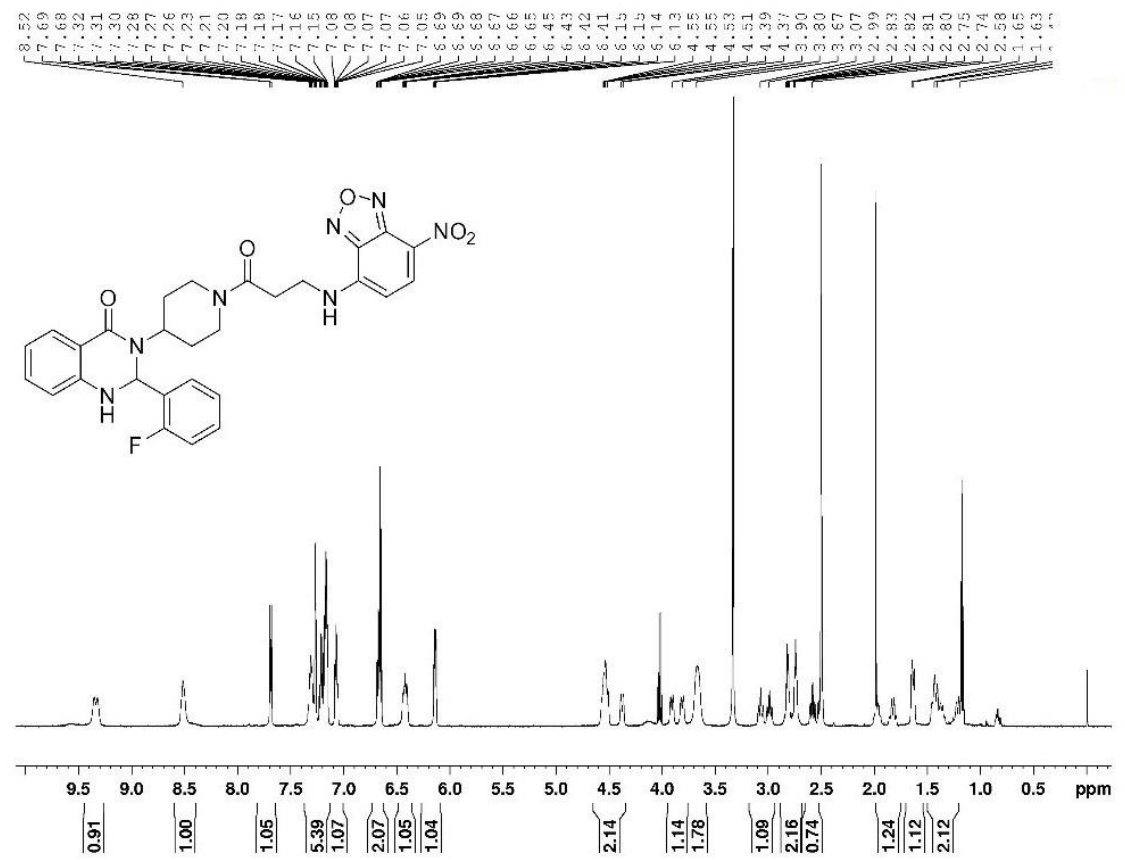

Figure S15. ${ }^{1} \mathrm{H}$ NMR spectrum of probe-2. 


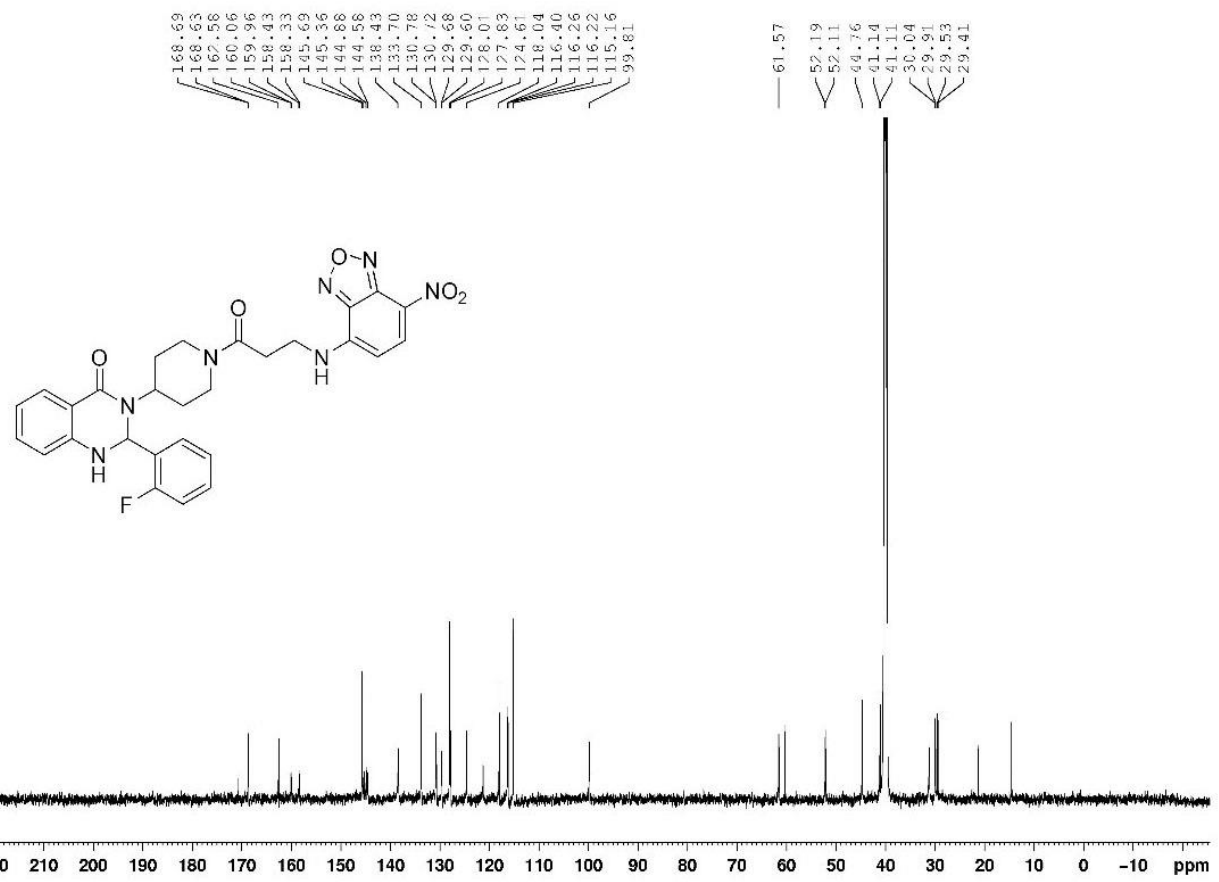

Figure S16. ${ }^{13} \mathrm{C}-\mathrm{NMR}$ spectrum of probe-2.

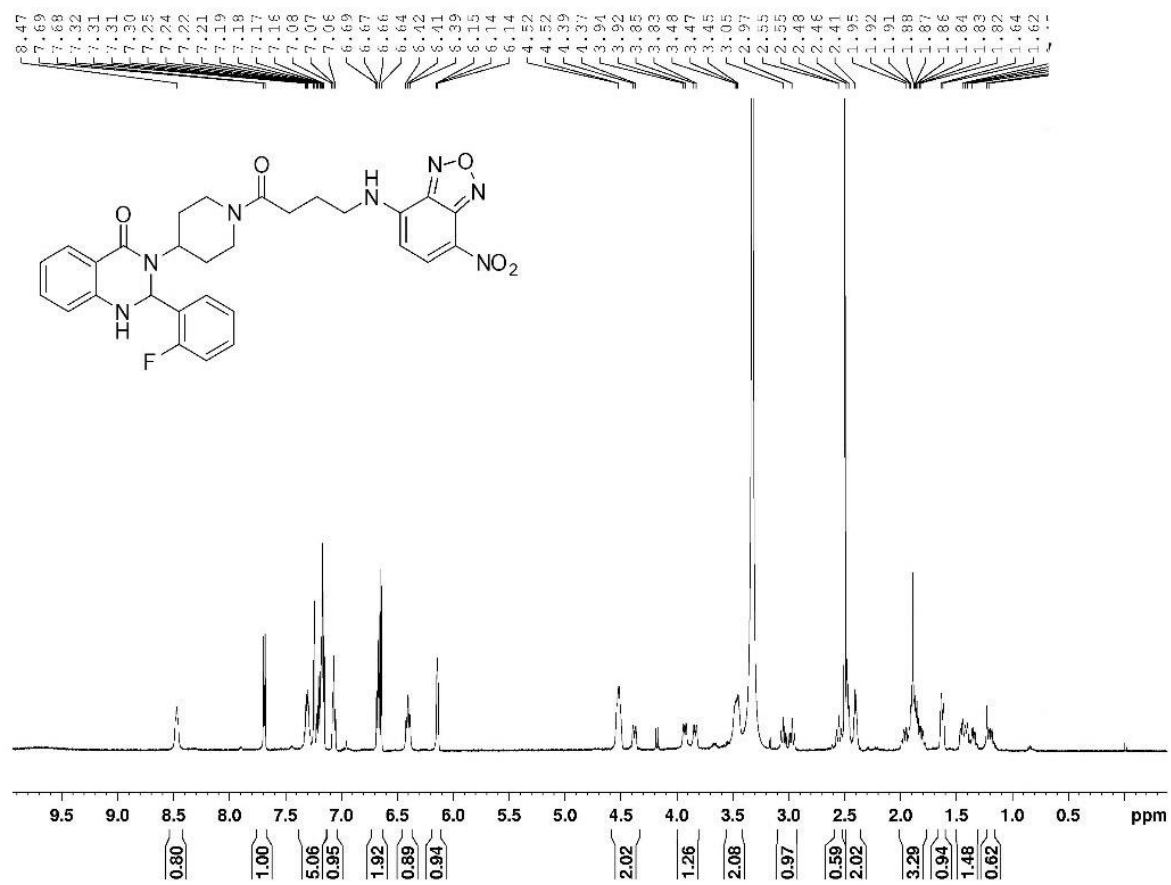

Figure S17. ${ }^{1} \mathrm{H}-\mathrm{NMR}$ spectrum of probe-3. 


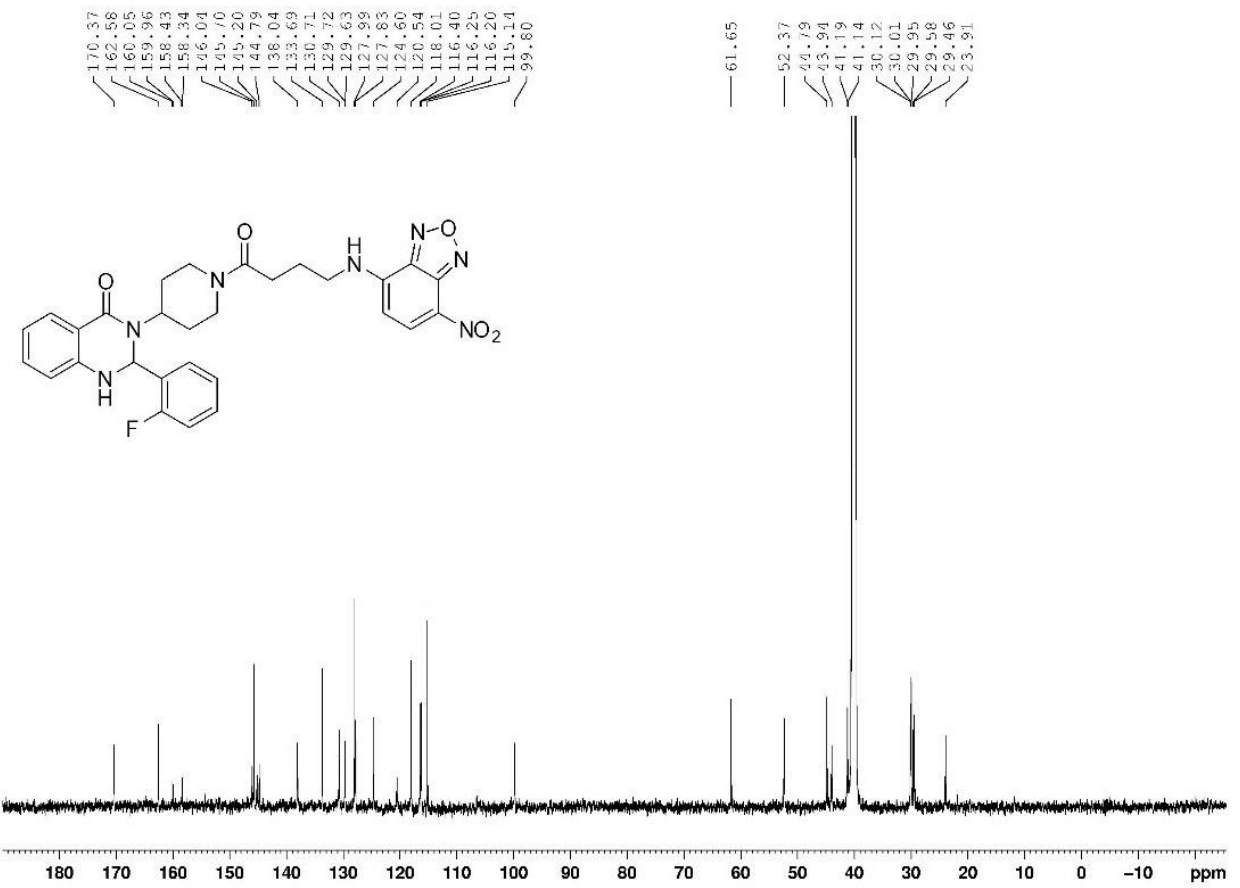

Figure S18. ${ }^{13} \mathrm{C}-\mathrm{NMR}$ spectrum of probe-3.

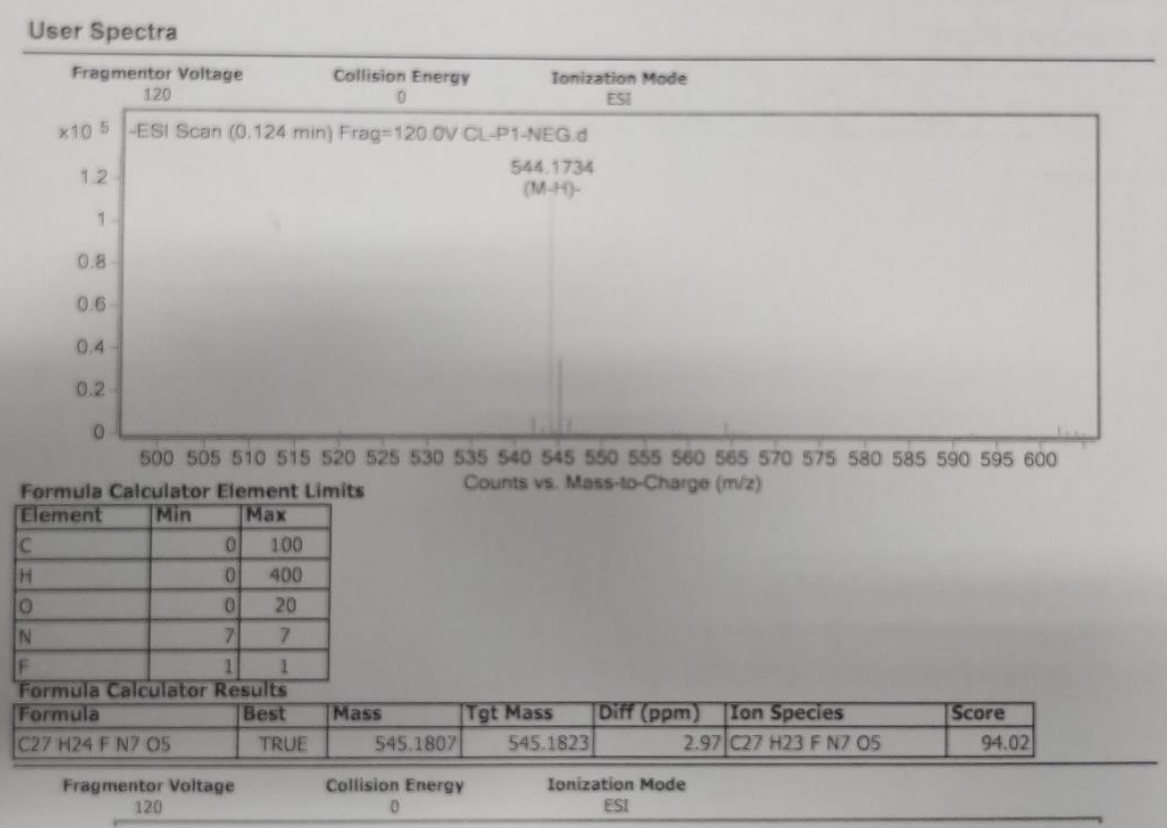




\section{Qualitative Analysis Report}

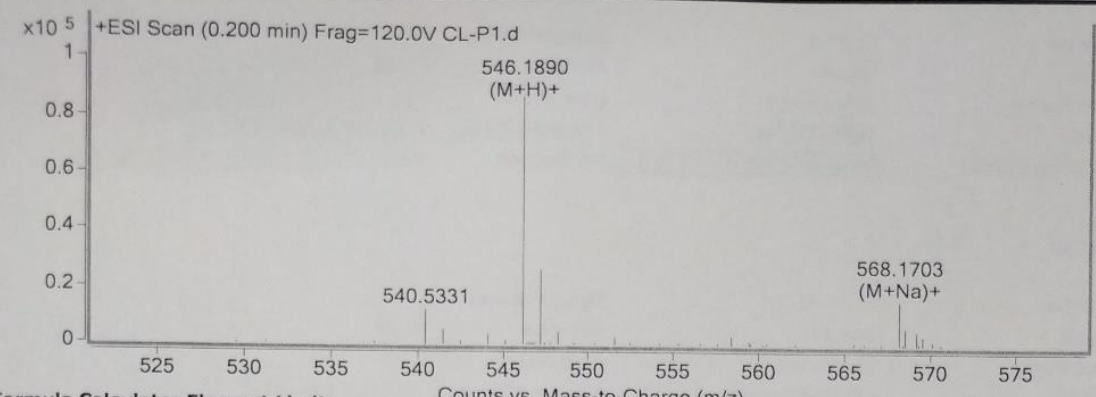

Formula Calculator Element Limits

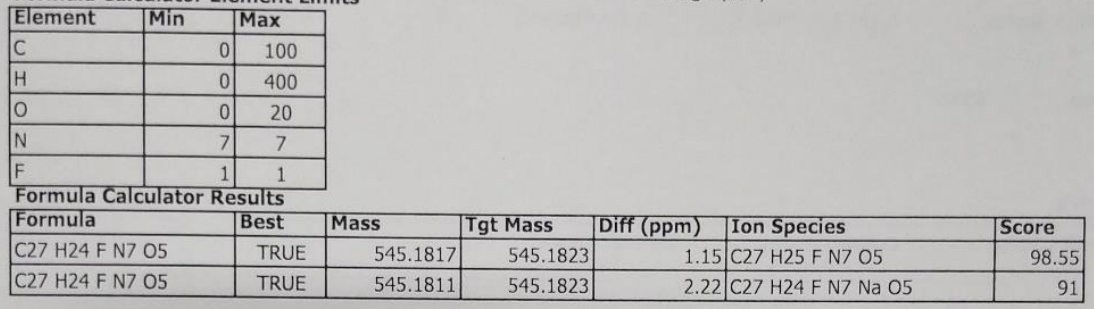

-.. End Of Report -..

Figure S19. HRMS(ESI) of probe-1.

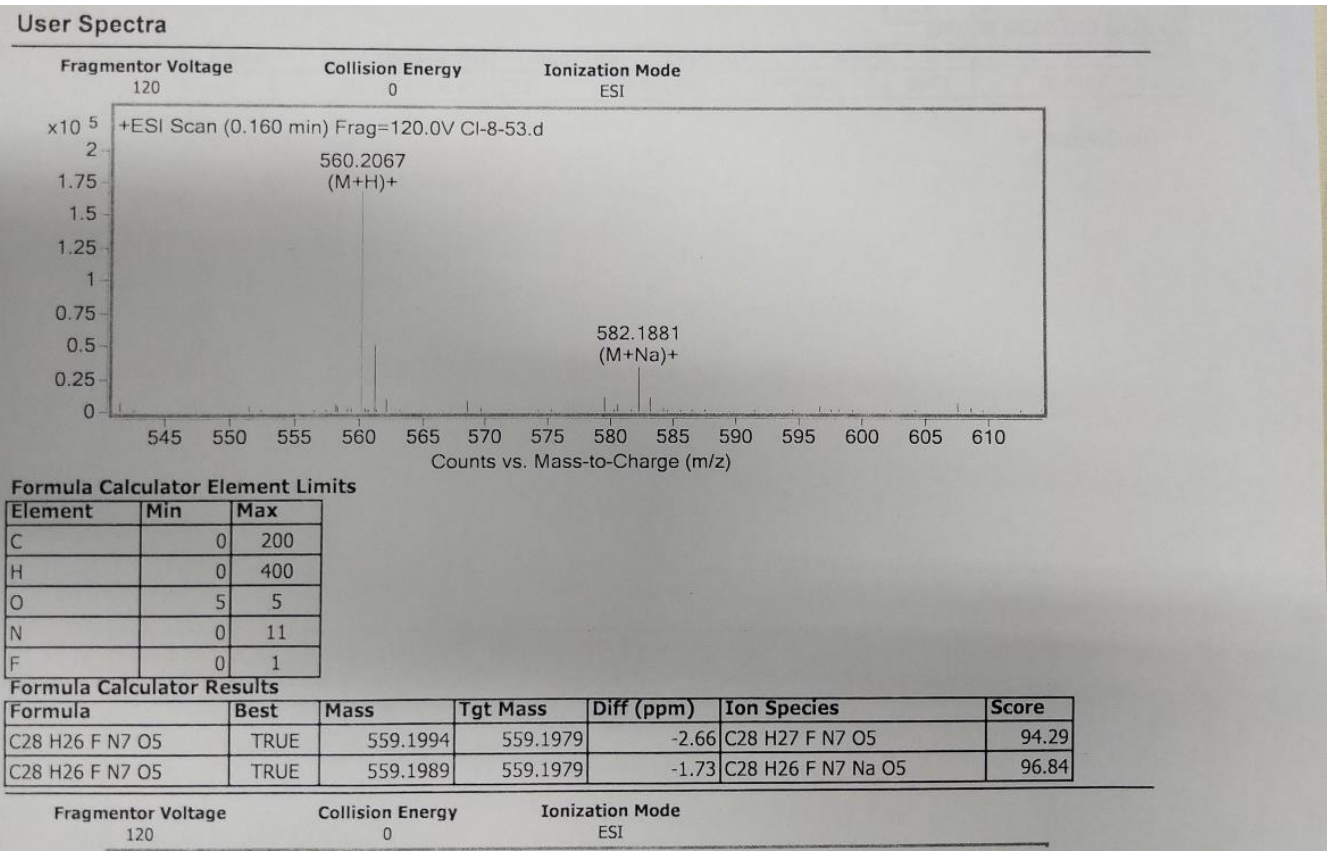


Qualitative Analysis Report

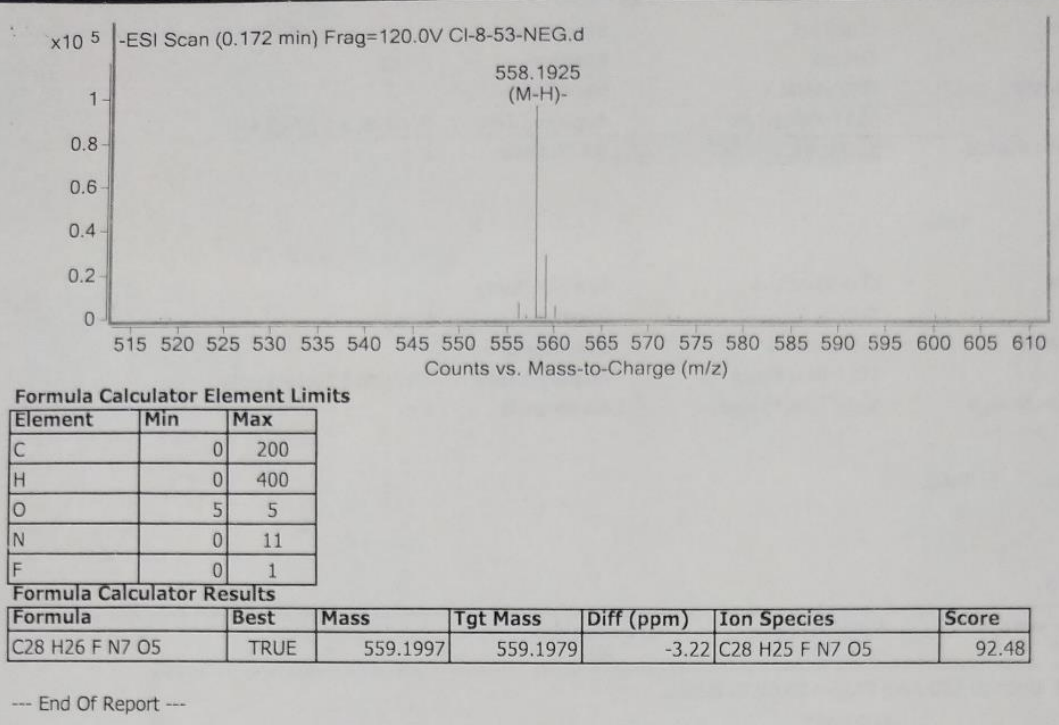

Figure S20. HRMS(ESI) of probe-2.

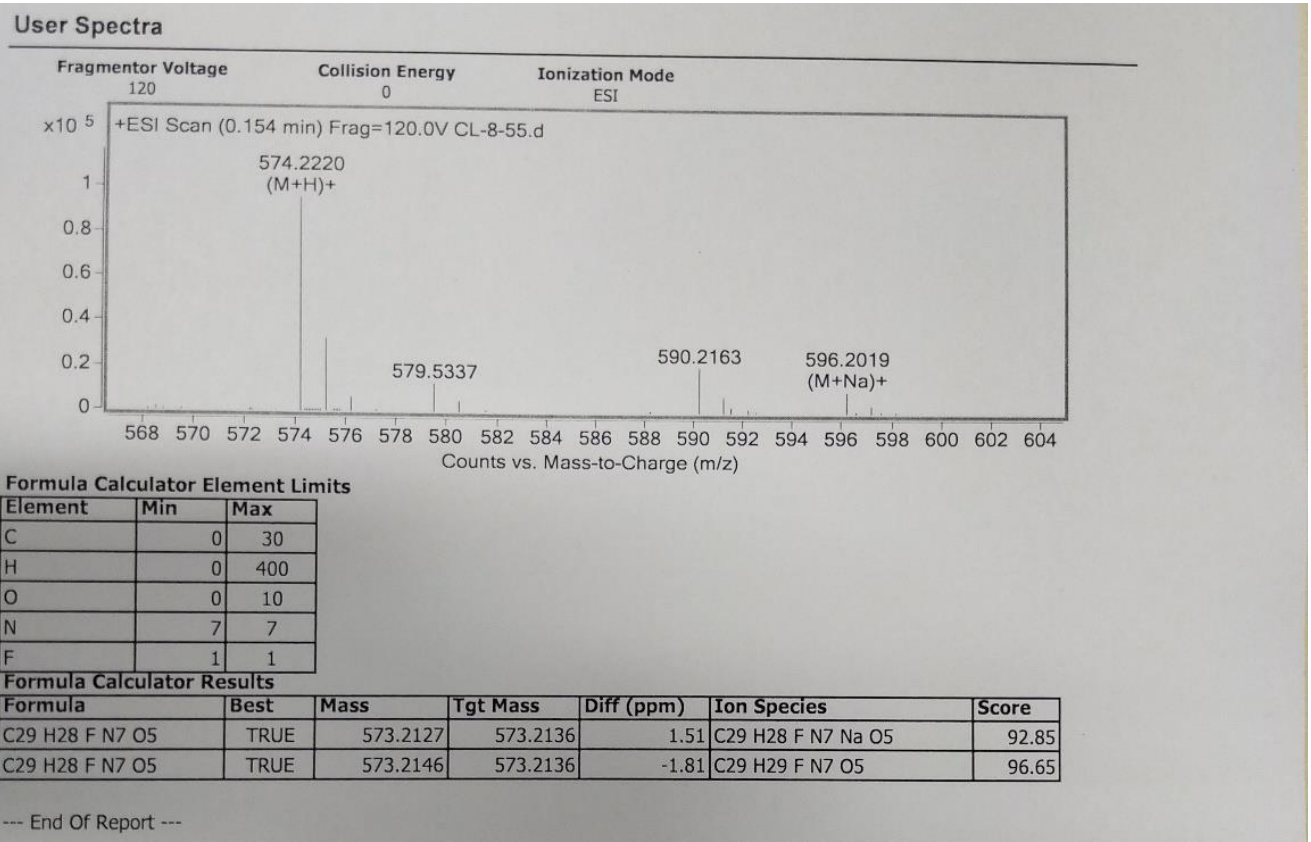

Figure S21. HRMS(ESI) of probe-3. 
HPLC Assessment of the Products Purity.

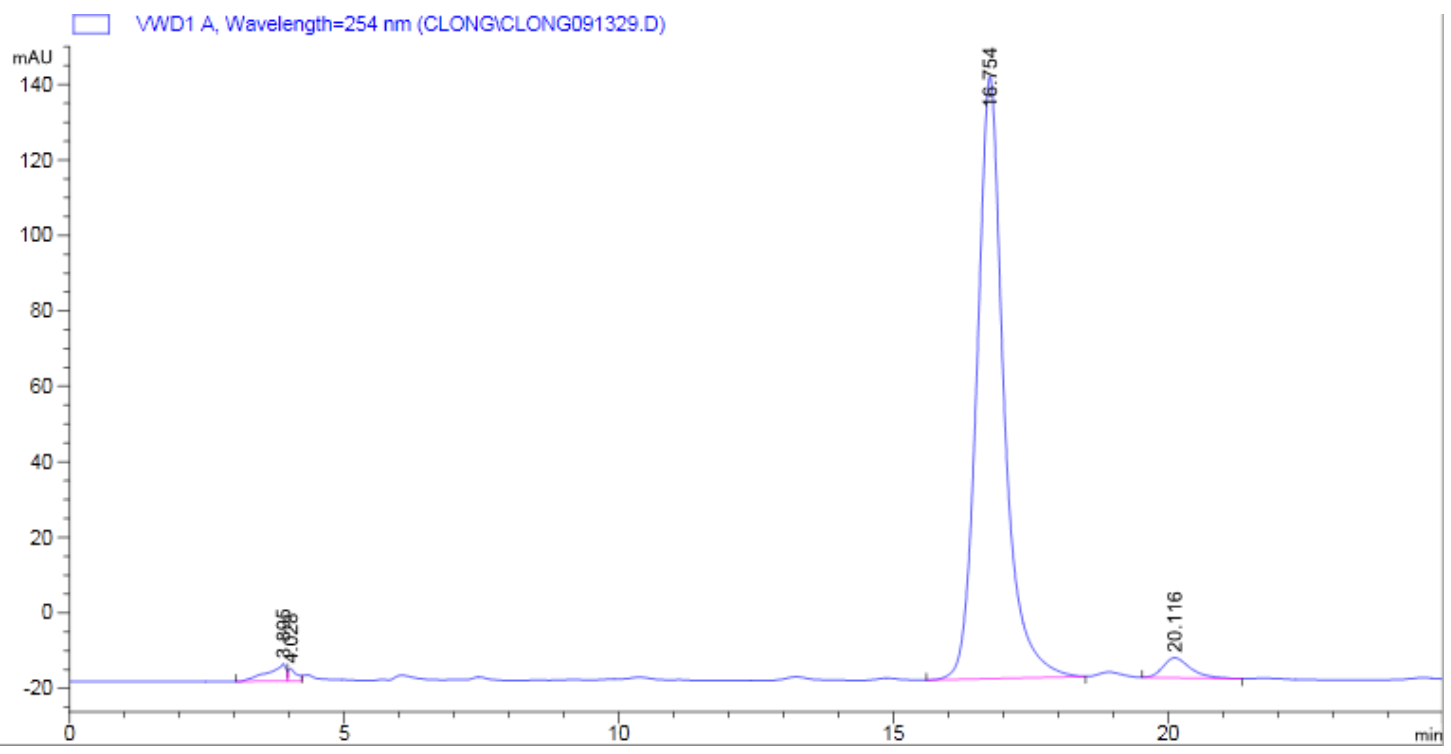

Figure S22. The purity of probe $\mathbf{1}$ is $94.39 \%$

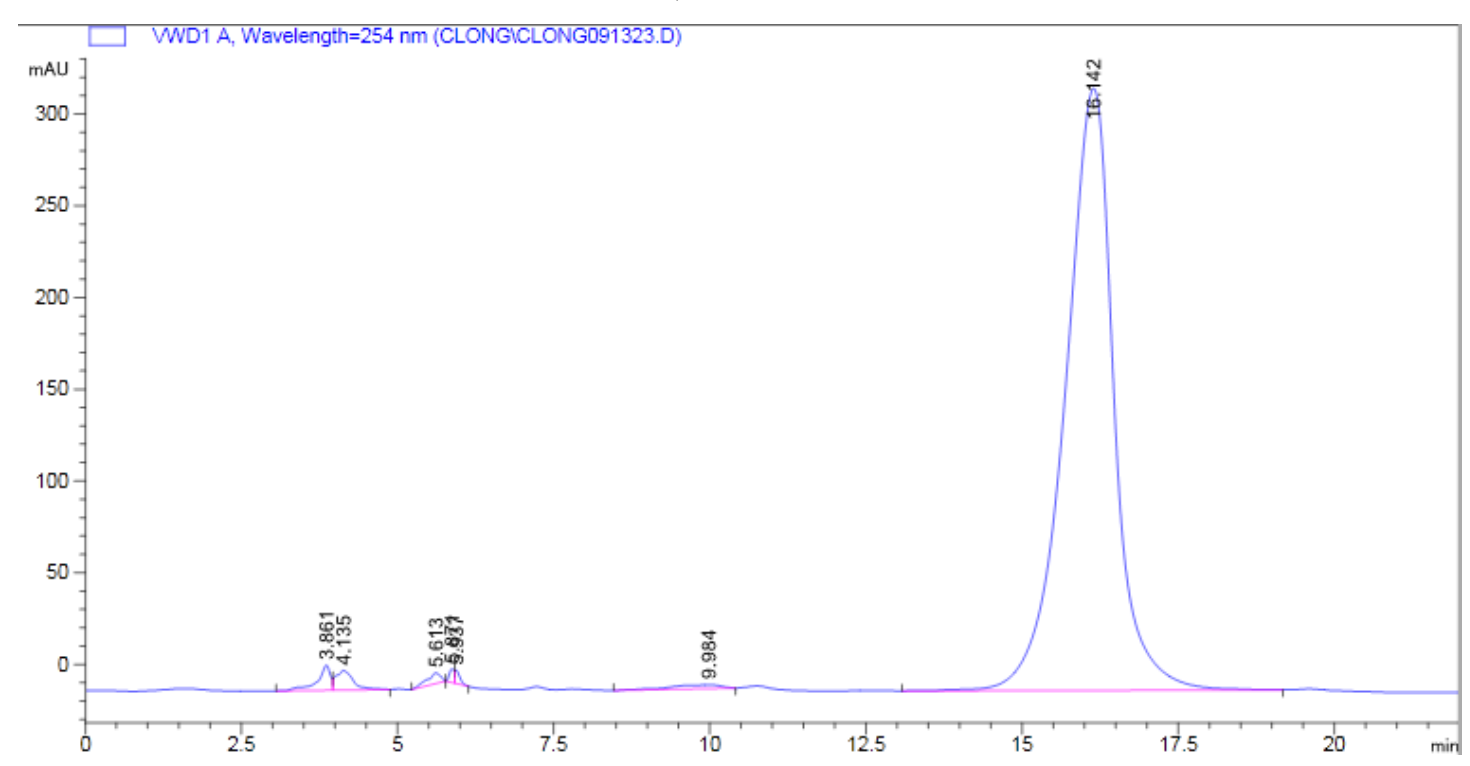

Figure S23. The purity of probe 2 is $96.3 \%$ 


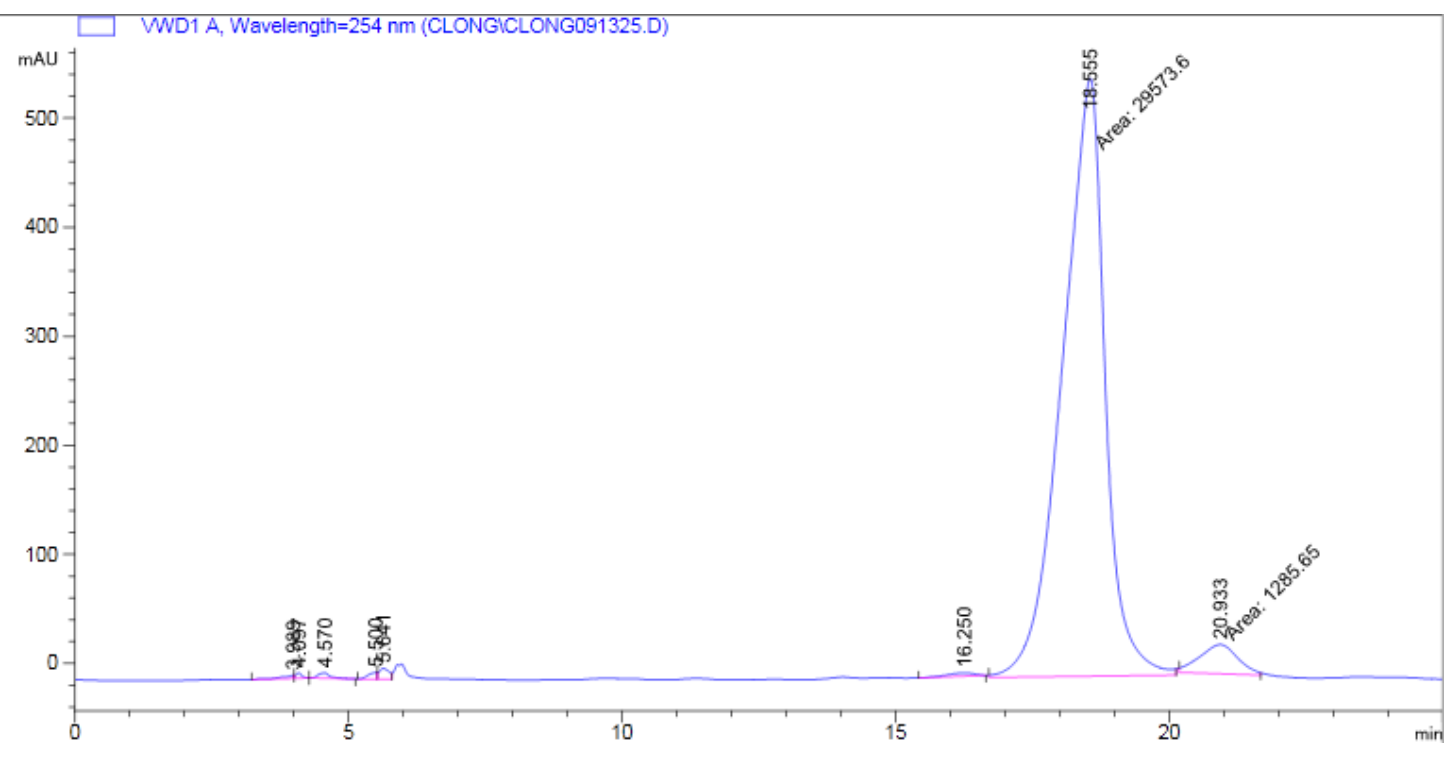

Figure S24. The purity of probe 3 is $94.48 \%$

\section{References}

(1) Jiang, Y.; Zhuang, C.; Chen, L.; Lu, J.; Dong, G.; Miao, Z.; Zhang, W.; Li, J.; Sheng, C. Journal of medicinal chemistry 2017, 60, 9400-9406.

(2) Dong, G.; He, S.; Qin, X.; Liu, T.; Jiang, Y.; Li, X.; Chen, L; Han, G.; Sheng, C.; Li, M. Analytical chemistry 2020, 92, 2642-2648.

(3) Chen, L.; Zhuang, C.; Lu, J.; Jiang, Y.; Sheng, C. Journal of medicinal chemistry 2018, 61, 26042610. 